\title{
Study of Groundwater in Northeast Cairo Area, Egypt
}

\author{
Salah Abdelwahab El-Sayed \\ Siting and Environmental Department, Nuclear and Radiological Regulatory Authority, Cairo, Egypt \\ Email: saelwahab132@yahoo.com
}

How to cite this paper: El-Sayed, S.A. (2018) Study of Groundwater in Northeast Cairo Area, Egypt. Journal of Geoscience and Environment Protection, 6, 229-251. https://doi.org/10.4236/gep.2018.64014

Received: February 7, 2018

Accepted: April 9, 2018

Published: April 12, 2018

Copyright $\odot 2018$ by author and Scientific Research Publishing Inc. This work is licensed under the Creative Commons Attribution International License (CC BY 4.0).

http://creativecommons.org/licenses/by/4.0/

\begin{abstract}
This paper presents a comprehensive hydrogeologic view of the Quaternary aquifer in north eastern Cairo area, Egypt. The hydrogeologic, hydrochemical and isotopic features of the aquifer are determined to assess the groundwater geochemistry and quality for different uses. The groundwater in the aquifer is shallow and flows towards the heavily pumping areas (cultivated and industrial areas). The concentrations of total dissolved solids (TDS) vary considerably in the aquifer, ranging from $225.6 \mathrm{mg} / \mathrm{L}$ to $1219 \mathrm{mg} / \mathrm{L}$. Wide variations in the concentrations of major ions, trace elements, nitrate, $\delta^{18} \mathrm{O}$ and $\delta^{2} \mathrm{H}$ are detected, indicating the variation in the geologic and recharge conditions. This further indicates the effect of natural processes (weathering, dissolution and ion exchange) as well as anthropogenic activities on the quality of groundwater. Moderate levels of contamination with nitrate, aluminum and manganese are recorded in the groundwater below the cultivated area. The contamination is linked to the extensive use of fertilizers for agriculture and the leakage of wastewater from improper sewage system. The computed nitrate pollution index reveals that about $69.69 \%$ of groundwater is safe for drinking, while the rest of groundwater is unsuitable. The calculated water quality index indicates that about $78.79 \%$ of groundwater is safe for human consumption and the rest of groundwater is poor for consumption because of the contamination with the high levels of manganese, total hardness, $\mathrm{pH}$, sulphate, aluminum, and nitrate. The contaminated groundwater needs to be treated before consumption. Hence, periodic groundwater quality checks are recommended.
\end{abstract}

\section{Keywords}

Northeast Cairo, Groundwater Geochemistry, Isotopes, Pollution, Water

Quality Assessment

\section{Introduction}

In recent years, the demand for groundwater has risen to the highest levels in 
Egypt due to the limited fresh-surface water resources. Nile River is the main source of water supply in Egypt. The assigned amount of Nile water to Egypt is about 55.5 billion cubic meters a year, which is not enough to cover the different life demands of the Egyptian people [1]. Therefore, the need for groundwater has increased to meet the steadily increase in population and the expansion in urbanization, agricultural and industrial projects. Beside the water of the Nile River, groundwater represents a natural strategic store of water supply for drinking, domestic and industrial purposes and others things which facilitate human life. In the Nile Valley and Delta regions of Egypt, the groundwater is available from the Nile aquifer system belonging to the Quaternary and Late Tertiary [2]. The withdrawal quantity of groundwater from the aquifer system attains 4.6 billion cubic meters a year [3].

Cairo, the capital of Egypt, is situated along the Nile Valley at its connection with the Nile Delta. It is located within the Nile River floodplain dominated by arid climatic conditions. During the last four decades, Cairo has experienced a rapid growth in population and a concurrent increase in water resources development. The population of Cairo has increased to reach 20 million with a population density of 19.376 people per $\mathrm{km}^{2}$ (Census 2016), and consequently the need to fresh water is steadily increasing.

The area selected for the current investigation, Northeast Cairo area (Figure 1), contains several industrial facilities and it has been earmarked for the building of new oil refinery units. The refineries are under construction and they were

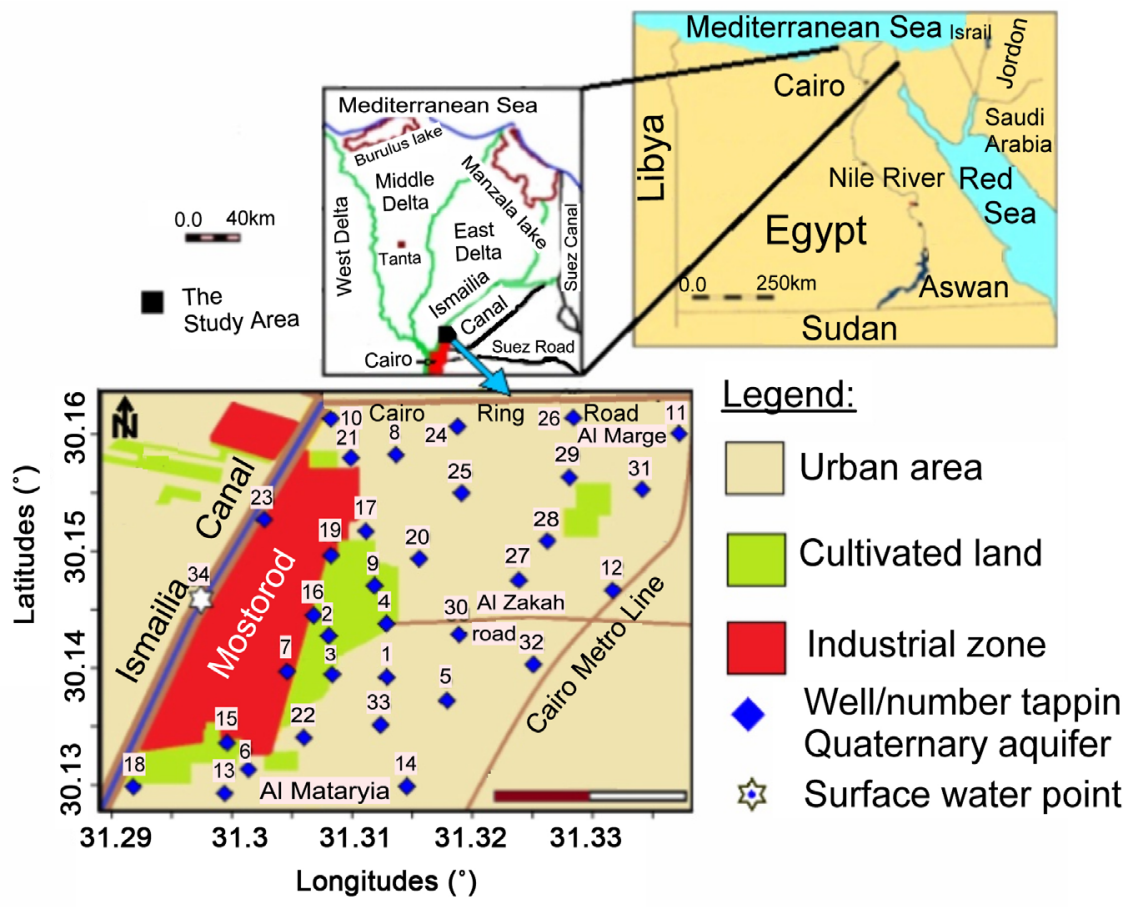

Figure 1. Location map of Northeast Cairo area, Egypt, showing the topographic features and sampling points (source of maps is Google earth, map data, 2016). 
expected to be completed by 2017 [4]. Accordingly, the water consumption is expected to increase with time and with urbanism.

In Northeast Cairo area, Nile water in Ismailia Canal and groundwater resources cannot be considered separately. As the fresh Nile water provided to the area through the governmental water pipelines is insufficient all the time and does not cover the whole life demands, the need to groundwater became a necessary issue for drinking and domestic purposes. Little is known about the groundwater conditions in the area under study. On a regional scale, some general hydrogeological information can be found in [5] [6] [7].

The Quaternary aquifer in the area is the main source of groundwater. Although the groundwater is currently used for drinking and domestic uses, knowledge about its occurrence, chemistry and quality is very limited. Therefore, this study aims at: 1) investigating the hydrogeologic environment where the groundwater flows, 2) providing hydrochemical baseline data about the intrinsic chemistry of groundwater (major ions, nutrients, trace elements), where there is no previous recorded data for the study area, 3) exploring the geochemical controls in the aquifer using the hydrochemical and stable isotopes (oxygen-18 and deuterium) analyses, and 4) assessing the quality of groundwater for different purposes using the common water quality indices. Finally, this work could be considered one of the environmental impact assessment investigations needed for the area before starting the operation of the new industrial projects. The outcomes are essential prerequisites for monitoring the pollution cases in future and for imposing the necessary regulatory limits.

\section{Area under Study}

\subsection{Location and Topography}

Northeast Cairo area is located at the southeastern part of the eastern Nile Delta, between latitudes $30.127^{\circ}$ to $30.160^{\circ} \mathrm{N}$ and longitudes $31.290^{\circ} \mathrm{E}$ to $31.340^{\circ} \mathrm{E}$. It is bounded by Ismailia Canal to the west and northwest, Cairo Ring Road to the north, El Marg-Helwan-Metro line to the east and El Mataryia urbanization area to the south (Figure 1). The area is characterized by an arid and dry climate with very hot summer and a mild winter. The yearly average rainfall intensity, relative humidity, maximum and minimum temperature are $4.14 \mathrm{~mm} /$ year, $59.5 \%$, $28.5^{\circ} \mathrm{C}$ and $14.6^{\circ} \mathrm{C}$, respectively. The dominating winds during the year times are from the N, NE and NW, with a maximum speed of about $8.7 \mathrm{~m} / \mathrm{s}$ [8]. The yearly average evaporation rate attains $10.1 \mathrm{~mm} /$ year [9].

The landscape of the area is essentially formed of three main landforms, the cultivated lands, Mostorod industrial zone and the urban areas. The cultivated lands are mainly found in the western part of the area (Figure 1). The main source of water for irrigation is the groundwater extracted from the Quaternary aquifer. The used irrigation method is the free flooding. The common chemical fertilizers used are nitrogen rich fertilizers such as $\mathrm{NH}_{4} \mathrm{NO}_{3}$ and $\left(\mathrm{NH}_{4}\right)_{2} \mathrm{SO}_{4}$, urea $\mathrm{NH}_{4} \mathrm{CONH}_{2}$ and base fertilizers such as $\mathrm{MnSO}_{4}[10]$. 
The industrial zone is located to the west of the cultivated area, overlooking Ismailia Canal. It accommodates several factories and companies including Mostorod Water Treatment Satiation, General Company for Ceramic and Porcelain Products, El Nasr Glass and Crystal Company, Misr Glass Manufacturing and Misr Aluminum and El Nasr Glass factories as well as Petro Gas, Petroleum Cooperative Society Company (COOP) and Cairo Oil Refining Company (CORC) [11] [12]. Currently, a major refinery expansion project (the Egyptian Re-fining Company, ERC) is underway. The project includes several new units and aims at upgrading the range of petroleum products [4]. The area located southwest of the industrial zone is currently used, without authorization, as waste dump for the household wastes and building materials.

The urban area surrounds the cultivated land and industrial zone from north, south and east directions. The establishment of Cairo Ring Road, Helwan-El Marge metro line and the expansion in the industrial activities are the main reasons for creating the high population density in this area. The urban area is served by fresh water pipelines coming from Mostorod water satiation situated in the southwestern part of the industrial area. Because of the shortage in the supplied fresh water, a huge number of unauthorized shallow-private wells have been drilled for water extraction. Unfortunately, many parts in the urban area are still without proper municipal sewage system.

\subsection{General Geology and Water Bearing Formations}

As part of the eastern Nile Delta, the study area is dominated by the Quaternary sediments consisting of Nile silts, sand dunes and sands and gravel. To the east of the area, the oldest Tertiary rocks (Pliocene, Miocene, Oligocene, and Eocene sediments) appear on the surface. A brief description of surface geologic formations is associated to Figure 2.

Table 1 shows the subsurface stratigraphic succession in the area and its vicinities. All rock units, but the Pliocene one, are considered water bearing formations [12] [13]. The Quaternary aquifer that is concerned by the present work has saturated thickness ranging from about $100 \mathrm{~m}$ in the study area to about $800 \mathrm{~m}$ near Mediterranean Sea [14] [15]. The major part of the groundwater is under semi-confining conditions. The Miocene, Oligocene and Eocene aquifers are of low significance because of their low quality waters. More details about the Tertiary aquifers can be found in [16] [17] [18] [19]. The sedimentary rocks belonging to Cretaceous, Jurassic, Triassic and Carboniferous periods have not been examined as water bearing formations in the whole area.

Tectonically, the eastern part of Nile Delta, comprising the study area, falls within the unstable shelf that dominates north Egypt [20]. It shows a very complicated structural pattern represented by large number of faults, folds (anticlines and synclines) and basaltic extrusion [19]. The faults are the prominent 


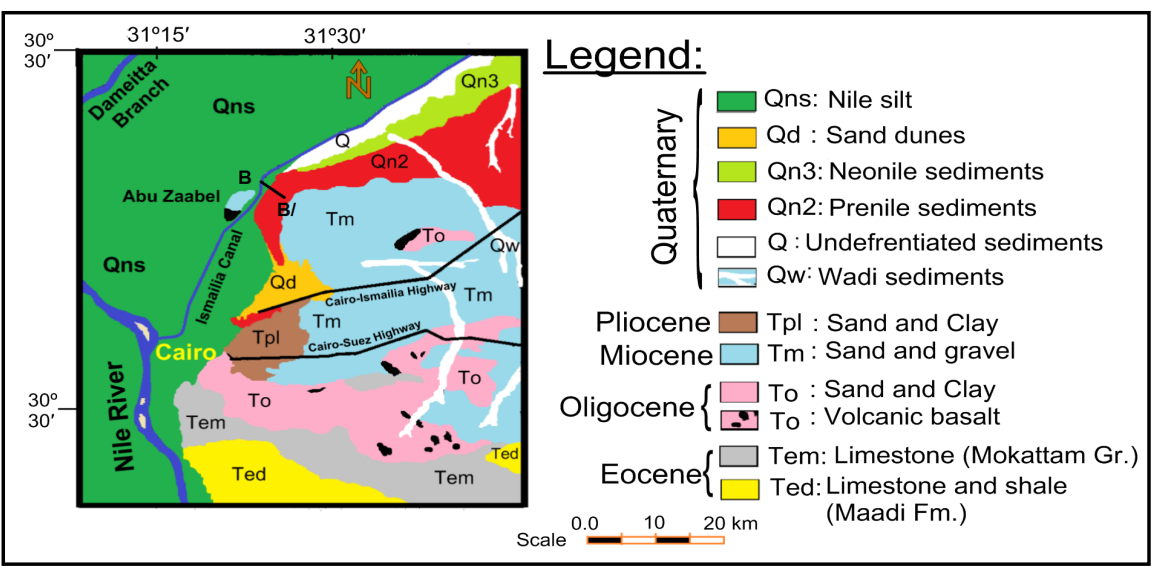

Figure 2. Geologic map of the study area and its vicinities, after [23].

Table 1. Generalized stratigraphic sequence in the Northeast Cairo area and its surroundings, after [24] [25].

\begin{tabular}{cccc}
\hline Age & Lithic description & Thickness, $\mathrm{m}$ & Hydrogeology \\
\hline Quaternary & Loose coarse quartz sand and flinty pebbles & 600 & Aquifer \\
Pliocene & $\begin{array}{c}\text { Pyretic and rarely fossiliferous marine clay } \\
\text { Miocene }\end{array}$ & 200 & Aquiclude \\
Oligocene & $\begin{array}{c}\text { Fluviatile and fluviomarine sandy series capped } \\
\text { marine origin } \\
\text { by basalt rocks }\end{array}$ & 250 & Aquifer \\
Eocene & $\begin{array}{c}\text { Dolomitic, sandy, marly and chalky } \\
\text { limestone with clay and sand beds } \\
\text { in the upper portion }\end{array}$ & 300 & Aquifer \\
\hline
\end{tabular}

structural features in the area. They follow three main regional trends, the NE-SW (Syrian Arc folding system), NW-SE (Suez Rift trend) and E-W (Mediterranean trend) directions [21]. Faults play an important role regarding the distribution of geologic formations and groundwater flow in the desert area. The faults rendered the Miocene deposits to face the Quaternary and Oligocene ones [22]. The Quaternary aquifer is hydraulically connected with the Miocene and Oligocene aquifers through fault planes [18]. Figure 3 is a hydrogeologic cross showing the hydraulic connection between these aquifers where one potentiometric surface is found to be common to all aquifers.

\subsection{Methodology}

An inventory of wells tapping the Quaternary aquifer, water level measurements, and sampling (water and aquifer materials) were taken from the study area in November 2015. Specification of the wells included the well heads, depths and diameters as well as screen and casing intervals. Depths to water inside these wells were measured and the coordinates and altitudes of wells were determined. Thirty three groundwater samples from the aquifer and one surface water sample from Ismailia Canal were collected for major ions, nutrients, trace elements 


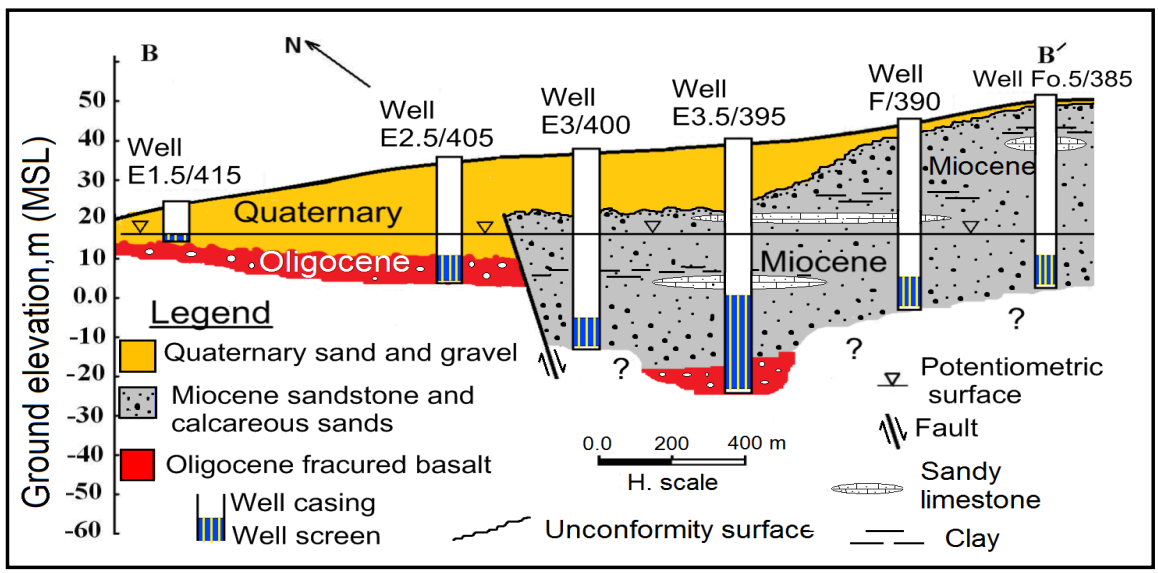

Figure 3. Hydrogeologic cross section in the area located to the northeast of the study area, showing the hydraulic connection between the Quaternary and Miocene aquifers, East Nile Delta area, slightly modified after [18].

and stable isotopes (oxygen- 8 and deuterium) analyses. All the wells were in use at the time of sampling. The discharge rates of these wells were slow to prevent or minimize degassing till the physical parameters of water ( $\mathrm{pH}$, specific conductance and total dissolved solids) stabilized. Then, the physical parameters were measured in-situ using Manta 2, Water-Quality Multiprobe device, Model Sub 3, USA. All the water samples were collected into light polyethylene bottles that had been rinsed with water from the wells. The water sample from the Ismailia Canal was filtered using $0.45 \mu \mathrm{m}$ pore-sized paper. For trace element analysis, all samples were acidified to $\mathrm{pH}<2$ with $20 \%$ nitric acid in order to prevent precipitation.

The water samples were processed and chemically analyzed following [26] at the Water and Soil Lab. Unit, Desert Research Center, Cairo, Egypt. Sodium and potassium were measured by a flame photometer; model PFP 7, Jenway, UK. Calcium and magnesium were determined by volumetric titration against $\mathrm{Na}_{2}$ EDITA. Chloride, carbonate and bicarbonate were identified by volumetric titration against silver nitrate and sulfuric acid. Sulphate was determined by a UV/Visible Spectrophotometer; model Unicam UV 300, Thermo Spectronic, USA. Trace elements were measured by Inductively Coupled Argon Plasma, ICAP 6500 Duo, Thermo Scientific, England. The detection limits of ICAP instrument were $0.02(\mathrm{Al}), 0.0006(\mathrm{Cd}), 0.001(\mathrm{Co}), 0.01(\mathrm{Cr}), 0.006(\mathrm{Cu}), 0.02$ $(\mathrm{Fe}), 0.002(\mathrm{Mn}), 0.001(\mathrm{Mo}), 0.002(\mathrm{Ni}), 0.008(\mathrm{~Pb}), 0.01(\mathrm{~V})$ and $0.001(\mathrm{Zn})$. Nutrient concentrations determined included nitrate and phosphate. They were analyzed by spectrophotometer; model UV-1601A, Shmadzu at the hydrologic Lab., Egyptian Nuclear and Radiological Regulatory Authority. Results of major ions and trace elements are reported in $\mathrm{mg} / \mathrm{L}$. Quality of major ion data was checked by comparing both the sum of cations (in meq/L) and the sum of anions (in meq/L). For all water samples, the reaction errors (\%) were less than $5 \%$. 
Fifteen water samples were selected and analyzed for oxygen-18 $\left({ }^{18} \mathrm{O}\right)$ and deuterium $\left({ }^{2} \mathrm{H}\right)$ using Isotope Ratio Mass Spectrometer, model Thermo-Finnigan Delta Plus XL. The oxygen and hydrogen contents are reported in delta per mil (\%o) relative to the international Vienna-standard mean ocean water (V-SMOW):

$$
\delta_{\text {sample }}=\left[\left(R_{\text {sample }}-R_{\text {standard }}\right) /\left(R_{\text {standard }}\right)\right] \times 1000
$$

where: $R$ sample is the ratio of ${ }^{18} \mathrm{O} /{ }^{16} \mathrm{O}$ or ${ }^{2} \mathrm{H} /{ }^{1} \mathrm{H}$ in the sample and $R$ standard is the ratio of the standard of known isotopic composition. The analytical precision

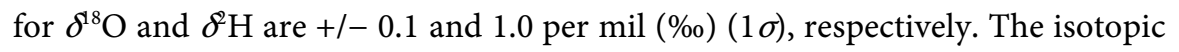
analyses were done in the Central Lab. for Environmental Isotope Hydrology, Egyptian Nuclear and Radiological Regulatory Authority, Egypt.

Total hardness (TH) and sodium adsorption ratio (SAR) of water samples were calculated for water samples according to [27]:

$$
\begin{gathered}
\mathrm{TH} \text { as } \mathrm{CaCO}_{3}(\mathrm{mg} / \mathrm{L})=2.5 \mathrm{Ca}^{2+}+4.1 \mathrm{Mg}^{2+} \\
\mathrm{SAR}=\mathrm{Na} /((\mathrm{Ca}+\mathrm{Mg}) / 2)^{0.5}
\end{gathered}
$$

Results of chemical and isotopic analyses were used to investigate the geochemistry of groundwater. The binary relationships $\left(\delta^{8} \mathrm{O}\right.$ vs. $\delta^{2} \mathrm{H}, \delta^{18} \mathrm{O}$ vs. $\mathrm{Cl}$, $\delta^{18} \mathrm{O}$ vs. $\mathrm{NO}_{3}, \mathrm{Na}$ vs. $\mathrm{Cl}, \mathrm{NO}_{3}$ vs. $\mathrm{Cl}, \mathrm{Mn}$ vs. $\mathrm{Cl}$, Mo vs. $\mathrm{Cl}, \mathrm{Zn}$ vs. $\mathrm{Cl}, \mathrm{Na} / \mathrm{Cl}$ vs. $\mathrm{Cl}$, $\mathrm{Ca} / \mathrm{Cl}$ vs. $\mathrm{Cl}, \mathrm{Mg} / \mathrm{Cl}$ vs. $\mathrm{Cl}, \mathrm{SO}_{4} / \mathrm{Cl}$ vs. $\mathrm{Cl}$ and $\mathrm{K} / \mathrm{Cl}$ vs. $\mathrm{Cl}$ ) were represented to delineate the influence of natural and anthropogenic factors on the chemistry of groundwater.

The groundwater quality was assessed for different drinking, domestic and irrigation purposes. For drinking use, the quality assessment was based on: 1) the contents of the measured inorganic constituents and in comparison with the Egyptian standards [28] [29], 2) the nitrate pollution index (NPI), and 3) the water quality index (WQI).

The NPI was calculated for all samples from the relation described in [30]:

$$
\mathrm{NPI}=(\mathrm{Cs}-\mathrm{HAV}) /(\mathrm{HAV})
$$

where Cs is the measured concentration in the sample and HAV is the threshold value of anthropogenic source (human affected value) taken as $20 \mathrm{mg} / \mathrm{L}$. The quality of water was classified into three types based on the values of NPI: clean (unpolluted), light pollution, moderate pollution, with the NPI value: $<0,0-1,1$ -2 , respectively.

The WQI was calculated using stepwise methods as described in [31] [32]:

$$
\begin{gathered}
\mathrm{WQI}=\sum_{i=1}^{n_{i}} S I_{i} \\
S I_{i}=W_{i} \cdot q_{i} \\
q_{i}=\left(C_{i} / S_{i}\right) \cdot 100
\end{gathered}
$$

where $q_{i}$ is the quality rating based on the concentration of $i^{\text {th }}$ parameter, $C_{i}$ is the concentration of each chemical parameter in each water sample in $\mathrm{mg} / \mathrm{L}, \mathrm{Si}$ 
is the drinking water standard for each chemical parameter in $\mathrm{mg} / \mathrm{L}$ [28] [29], $W_{i}$ is the relative weight assigned for each parameter, $S I_{i}$ is the subindex of $i^{\text {th }}$ parameter, $n$ is the number of parameters. Here eighteen parameters $(\mathrm{pH}$, TDS, TH, $\mathrm{Na}, \mathrm{Ca}, \mathrm{Mg}, \mathrm{Cl}, \mathrm{SO} 4, \mathrm{NO}_{3}, \mathrm{Fe}, \mathrm{Mn}, \mathrm{Cu}, \mathrm{Zn}, \mathrm{Al}, \mathrm{Pb}, \mathrm{Cd}, \mathrm{Cr}$, and $\mathrm{Ni}$ ) were used to compute the WQI, and the Egyptian standards for dinking water were used to estimate the quality rating. For the groundwater samples having metal concentrations below the detection limits, concentration values equal to half the detection limit are used in the quality rating calculations. The quality of water was classified into three types based on the WQI values: excellent, good, and poor with the WQI values: $<50,50-100,101-200$, respectively.

For domestic uses, the assessment of the groundwater quality was based on its content of water quality index (WQI), which was calculated using the same stepwise methods described above. Here 13 chemical parameters were used to compute the WQI, they included the $\mathrm{pH}$, TDS, TH, Na, Ca, $\mathrm{Mg}, \mathrm{Cl}, \mathrm{SO}_{4}, \mathrm{Fe}, \mathrm{Mn}$, $\mathrm{Cu}, \mathrm{Zn}$, and Al. The Egyptian domestic water standard [28] [29] for each chemical parameter was used to calculate the quality rating. The quality of water for domestic uses was classified into three categories based on the WQI values: excellent, good, and poor with the WQI value: $<50,50-100,101-200$, respectively [32].

For irrigation use, the quality assessment was based on the water quality index (WQI), which was computed using the stepwise method described above. Here 13 chemical parameters including SAR, EC, $\mathrm{TH}, \mathrm{pH}, \mathrm{Na}, \mathrm{Ca}, \mathrm{Mg}, \mathrm{K}, \mathrm{Cl}, \mathrm{SO}_{4}$, $\mathrm{HCO}_{3}, \mathrm{NO}_{3}$ and $\mathrm{PO}_{4}$ were used to compute the WQI. The FAO irrigation standard [33] for each parameter was applied to calculate the quality rating. The quality of water for irrigation use was classified into three classes based on the WQI values: Class I (non restriction), Class II (slight restriction), and class III (moderate restriction) and with the WQI value: $<150,150-300,300-450$, and $>450$, respectively, [32].

\section{Results}

\subsection{Hydrogeologic Signature}

The Quaternary aquifer in the study area is penetrated by a great number of private shallow wells. Most of these wells are found in the urban area, and their water is generally used for drinking and domestic uses. A few wells (Nos. 2, 7, and 9) are found in the agricultural lands around the industrial zone, and their water is used mainly for irrigation. All wells were drilled using hand-dug method. Depths of these wells range from $12 \mathrm{~m}$ to $55 \mathrm{~m}$, and their diameters range from 2 inches to 6 inches. The screen lengths range from $2.5 \mathrm{~m}$ to $20 \mathrm{~m}$ followed by sand traps. The casing and screen of wells are made of galvanized steel. These wells represent the main source of geologic, hydrogeologic and hydrochemical data used to conduct this study. The lithologic data are used to construct the hydrogeologic cross sections (Figure 4(a), Figure 4(b)) and the water level measurements are used to construct the depth to water and potentiometric surface contour maps (Figure 5). 


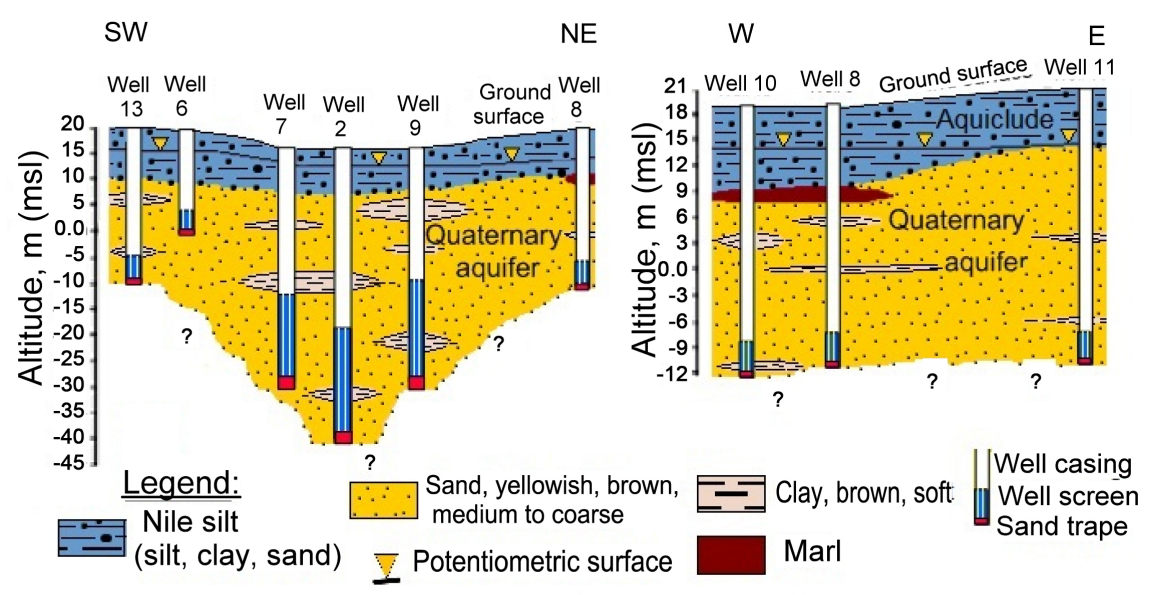

(a)

(b)

Figure 4. Hydrogeologic cross sections; (a) a SW-NE and (b) an E-W, the Quaternary aquifer, Northeast Cairo area, Egypt.

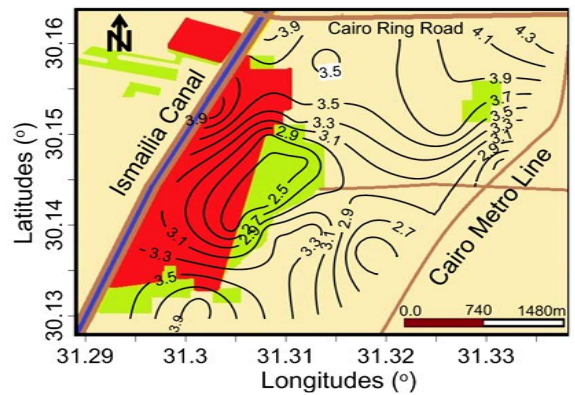

(a)

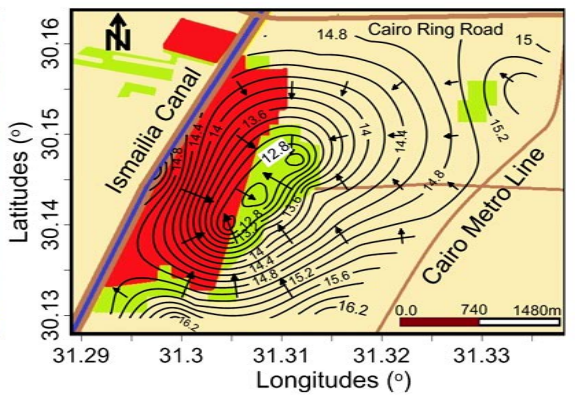

(b)

Figure 5. Depth to water and potentiometric surface contour maps of the Quaternary aquifer, Northeast Cairo area, Egypt. (a) Depth to water; (b) Groundwater altitude and flow lines.

\subsection{Hydrochemical Signature}

A complete tabulation of the analytical data including physico-chemical parameters, major ions, nutrients and trace elements of groundwater samples taken from the Quaternary aquifer and Ismailia Canal are shown in Table 2 and Table 3. The groundwater has slight alkaline to alkaline nature. The electrical conductivity (EC) values indicate a very weakly to weakly mineralized water according to [34]. Concentrations of total dissolved solids (TDS) are variable and indicate a good potable to fairly fresh water according to [35]. The Nile water in Ismailia Canal is alkaline, dilute and has the lowest E C and TDS values (Table 2).

Concentrations, arrangement and distribution of major ions vary greatly in the Quaternary aquifer. About $66 \%$ and $33 \%$ of the studied groundwater samples are, respectively, dominated by $\mathrm{Ca}^{2+}$ and $\mathrm{Mg}^{2+}$ ions, while about $42 \%, 30 \%$ and $27 \%$ of the samples are dominated by $\mathrm{SO}_{4}{ }^{2-}, \mathrm{HCO}_{3}{ }^{-}$and $\mathrm{Cl}^{-}$ions, respectively. Accordingly, the groundwater in the area belongs to sulphate, chloride and carbonate waters as large geochemical groups. 
Table 2. Altitudes, physico-chemical parameters, major ion composition and nutrients of groundwater, the Quaternary aquifer, Northeast Cairo area, Egypt.

\begin{tabular}{|c|c|c|c|c|c|c|c|c|c|c|c|c|c|c|c|c|c|}
\hline \multirow{2}{*}{$\begin{array}{l}\text { Well } \\
\text { No. }\end{array}$} & \multirow{2}{*}{$\begin{array}{c}\text { Depth to } \\
\text { water, } \\
\left(\mathrm{m},{ }^{\star} \mathrm{GS}\right)\end{array}$} & \multirow{2}{*}{$\begin{array}{l}\text { Water level } \\
\left(\mathrm{m},{ }^{* *} \mathrm{MSL}\right)\end{array}$} & \multirow{2}{*}{$\mathrm{pH}$} & \multirow{2}{*}{\multicolumn{2}{|c|}{$\begin{array}{cc}\text { EC } & \text { TDS } \\
(\mu \mathrm{S} / \mathrm{cm}) & (\mathrm{mg} / \mathrm{L})\end{array}$}} & \multicolumn{4}{|c|}{ Major anions } & \multicolumn{4}{|c|}{ Major cations } & \multicolumn{2}{|c|}{ Nutrients } & \multicolumn{2}{|c|}{ Stable isotopes } \\
\hline & & & & & & $\begin{array}{l}\mathrm{HCO}_{3} \\
(\mathrm{mg} / \mathrm{L})\end{array}$ & $\begin{array}{c}\mathrm{CO}_{3} \\
(\mathrm{mg} / \mathrm{L})\end{array}$ & $\begin{array}{c}\mathrm{SO}_{4} \\
(\mathrm{mg} / \mathrm{L})\end{array}$ & $\begin{array}{c}\mathrm{Cl} \\
(\mathrm{mg} / \mathrm{L})\end{array}$ & $\begin{array}{c}\mathrm{Ca} \\
(\mathrm{mg} / \mathrm{L})\end{array}$ & $\begin{array}{c}\mathrm{Mg} \\
(\mathrm{mg} / \mathrm{L})\end{array}$ & $\begin{array}{c}\mathrm{Na} \\
(\mathrm{mg} / \mathrm{L})\end{array}$ & $\begin{array}{c}\mathrm{K} \\
(\mathrm{mg} / \mathrm{L})\end{array}$ & $\begin{array}{c}\mathrm{NO}_{3} \\
(\mathrm{mg} / \mathrm{L})\end{array}$ & $\begin{array}{c}\mathrm{PO}_{4} \\
(\mathrm{mg} / \mathrm{L})\end{array}$ & $\begin{array}{c}\delta^{18} \mathrm{O} \\
\%\end{array}$ & $\delta \mathrm{D}, \%$ \\
\hline 1 & 3.44 & 14.32 & 8.7 & 1132 & 608.7 & 158.6 & 14 & 198.5 & 98.6 & 22.74 & 35.43 & 101.3 & 58 & 12.89 & 0.25 & 1.12 & 13.05 \\
\hline 2 & 2.33 & 12.47 & 7.6 & 1952 & 1213 & 100 & Nil & 495 & 294.1 & 190.2 & 75 & 90.2 & 18 & 55.2 & 0.02 & 3.28 & 27.99 \\
\hline 3 & 3.25 & 13.65 & 8.2 & 729 & 369.0 & 128.1 & Nil & 122.3 & 21.3 & 47.8 & 13.2 & 27.6 & 16 & 11.9 & 0.03 & - & - \\
\hline 4 & 2.85 & 13.95 & 8.2 & 1023 & 630.6 & 158.6 & Nil & 118.1 & 142.6 & 51.25 & 30.26 & 83.5 & 16 & 8.54 & 0.03 & - & - \\
\hline 5 & 2.3 & 15.3 & 8.2 & 522 & 260.4 & 128.1 & Nil & 35.9 & 59.3 & 37.43 & 11.48 & 15.5 & 37 & 11.21 & 0.05 & - & - \\
\hline 6 & 3.99 & 15.32 & 8.2 & 994 & 568.4 & 180.2 & Nil & 198.5 & 87.6 & 51.69 & 32.73 & 81.3 & 27 & 11.6 & 0.04 & - & - \\
\hline 7 & 2.4 & 12.47 & 8.0 & 1562 & 935.6 & 112.2 & Nil & 372.8 & 218.7 & 153.2 & 47.6 & 69.3 & 18 & 34.64 & 0.02 & - & - \\
\hline 8 & 3.78 & 14.55 & 9.2 & 567 & 319.1 & 42.7 & 12 & 129.9 & 50.7 & 18.3 & 17.84 & 52.8 & 16 & 7.55 & 0.04 & 2.3 & 23.22 \\
\hline 9 & 2.45 & 12.47 & 8.1 & 719 & 385.5 & 101.3 & Nil & 112.5 & 96.4 & 56.3 & 25.38 & 36.9 & 7 & 4.53 & 0.02 & 2.33 & 19.89 \\
\hline 10 & 3.2 & 14.85 & 8.9 & 636 & 371.1 & 134.2 & Nil & 112.3 & 21.3 & 40.6 & 13.43 & 31.74 & 7 & 5.26 & 0.03 & - & - \\
\hline 11 & 4.45 & 14.86 & 8.4 & 444 & 225.6 & 158.6 & Nil & 27.9 & 38 & 33.95 & 11.87 & 27.8 & 7 & 7.25 & 0.03 & - & - \\
\hline 12 & 2.35 & 15.1 & 8.5 & 1108 & 540.3 & 111 & Nil & 187.2 & 119.2 & 43.38 & 32.77 & 80 & 22 & 9.22 & 0.04 & - & - \\
\hline 13 & 3.9 & 16.45 & 8.3 & 677 & 251.2 & 46.97 & Nil & 133.44 & 31.24 & 51 & 14.64 & 14.8 & 3 & 7.99 & 0.03 & - & - \\
\hline 14 & 3 & 16.4 & 8.2 & 581 & 236.9 & 176.9 & Nil & 54.2 & 39.3 & 77 & 9.41 & 10.58 & 10 & 6.67 & 0.06 & 0.39 & 3.8 \\
\hline 15 & - & - & 7.8 & 999 & 599.5 & 150.67 & 10 & 187.2 & 111.82 & 113.8 & 21.48 & 57.96 & 6.4 & 40.37 & 0.26 & - & - \\
\hline 16 & - & - & 8.2 & 1152 & 640.9 & 109.19 & Nil & 163.2 & 150.87 & 96.2 & 29.64 & 62.33 & 12.4 & 28.75 & 0.42 & - & - \\
\hline 17 & 3.40 & 13.36 & 8.2 & 1184 & 769.3 & 117.73 & 12 & 279.36 & 172.17 & 136.6 & 43.68 & 55.66 & 4.4 & 18.6 & 0.65 & 4.38 & 30.09 \\
\hline 18 & 3.33 & 14.80 & 8.5 & 1216 & 805.6 & 122.61 & Nil & 179.52 & 189.92 & 74.8 & 36.6 & 98.44 & 17.2 & 42.13 & 0.55 & 3.5 & 30.10 \\
\hline 19 & 2.60 & 13.1 & 7.9 & 1564 & 920.2 & 81.13 & Nil & 255.84 & 234.3 & 78.4 & 55.44 & 123.05 & 18.4 & 53.22 & 0.47 & 4.11 & 33.91 \\
\hline 20 & - & - & 7.8 & 1944 & 1080 & 268.4 & 11 & 283.2 & 248.5 & 193.6 & 59.64 & 72.45 & 20 & 45.11 & 0.34 & 4.81 & 34.80 \\
\hline 21 & - & - & 8.1 & 1949 & 1190 & 122 & 14 & 384 & 266.25 & 187 & 53.04 & 106.95 & 14.8 & 52.8 & 0.67 & 3.9 & 28.43 \\
\hline 22 & - & - & 7.6 & 1960 & 1219 & 275.11 & Nil & 291.84 & 269.8 & 184.6 & 54.72 & 108.33 & 24.4 & 56.47 & 0.72 & 5.16 & 33.91 \\
\hline 23 & 4.1 & 14.32 & 8.5 & 792 & 440.6 & 144.57 & Nil & 99.84 & 92.3 & 63.8 & 21.84 & 46.69 & 17.6 & 25.36 & 0.02 & +2.2 & +20.52 \\
\hline 24 & 3.55 & 14.83 & 8.3 & 770 & 428.3 & 193.37 & Nil & 109.44 & 67.45 & 65 & 17.04 & 48.07 & 14 & 6.24 & 0.04 & - & - \\
\hline 25 & 3.6 & 14.32 & 8.8 & 963 & 566.8 & 111.02 & Nil & 150 & 79.875 & 64 & 21.96 & 46.46 & 34 & 3.22 & 0.08 & - & - \\
\hline 26 & - & - & 8.9 & 678 & 399.9 & 156.77 & Nil & 68.64 & 21.3 & 27.8 & 11.16 & 40.25 & 10.8 & 4.89 & 0.06 & - & - \\
\hline 27 & - & - & 8.8 & 646 & 380.6 & 241.56 & 14 & 144 & 71 & 130.4 & 10.8 & 27.14 & 28 & 5.29 & 0.04 & - & - \\
\hline 28 & 3.90 & 14.74 & 8.2 & 918 & 510.7 & 91.5 & Nil & 187.2 & 102.95 & 37.6 & 32.04 & 80.04 & 26.8 & 3.28 & 0.03 & - & - \\
\hline 29 & - & - & 7.8 & 1138 & 579.5 & 188.49 & Nil & 360 & 106.5 & 174 & 24.6 & 70.15 & 14.4 & 3.69 & 0.05 & - & - \\
\hline 30 & - & - & 8.7 & 635 & 364.8 & 286.7 & 10 & 79.92 & 17.75 & 81.8 & 12.6 & 36.11 & 12.4 & 4.5 & 0.07 & 0.65 & 11.31 \\
\hline 31 & 3.8 & 15.6 & 8.9 & 578 & 340.2 & 290.97 & Nil & 116.64 & 21.3 & 84.4 & 12.72 & 40.02 & 15.6 & 3.19 & 0.03 & -0.19 & 3.4 \\
\hline 32 & 2.90 & 15.06 & 8.5 & 813 & 478.1 & 245.22 & Nil & 76.8 & 21.3 & 33.6 & 27.84 & 22.08 & 18.8 & 8.5 & 0.03 & - & - \\
\hline 33 & - & - & 8.9 & 548 & 322.4 & 214.72 & Nil & 99.84 & 21.655 & 88.4 & 18.24 & 11.96 & 13.2 & 6.77 & 0.04 & - & - \\
\hline 34 & & & & & & & & & & & & & & & & & \\
\hline $\begin{array}{c}\text { Ismailia } \\
\text { Canal }\end{array}$ & - & 15.6 & 9.2 & 359 & 211.5 & 117.73 & 12 & 29.76 & 16.33 & 19.8 & 15.96 & 11.5 & 5 & 6.24 & 0.02 & +3.42 & +29.4 \\
\hline
\end{tabular}

${ }^{*}$ GS: ground surface; ${ }^{* *}$ MSL: mean sea level. 
Table 3. Concentrations of some trace elements in groundwater of the Quaternary aquifer, Northeast Cairo area, Egypt.

\begin{tabular}{|c|c|c|c|c|c|c|c|c|c|c|c|c|}
\hline $\begin{array}{c}\text { Sample } \\
\text { No. }\end{array}$ & $\mathrm{Al}$ & $\mathrm{Cd}$ & Co & $\mathrm{Cr}$ & $\mathrm{Cu}$ & $\mathrm{Fe}$ & $\mathrm{Mn}$ & Mo & $\mathrm{Ni}$ & $\mathrm{Pb}$ & $\mathrm{V}$ & $\mathrm{Zn}$ \\
\hline 1 & 0.1439 & $<0.0006$ & $<0.001$ & $<0.01$ & $<0.006$ & $<0.02$ & 0.0492 & 0.0120 & 0.0035 & $<0.008$ & 0.0772 & 0.0131 \\
\hline 2 & 0.1012 & $<0.0006$ & $<0.001$ & 0.0241 & 0.0545 & $<0.02$ & 0.3132 & 0.0028 & $<0.002$ & $<0.008$ & $<0.01$ & 0.0070 \\
\hline 3 & 0.0271 & $<0.0006$ & $<0.001$ & $<0.01$ & $<0.006$ & 0.0413 & 0.0112 & 0.0045 & $<0.002$ & $<0.008$ & 0.0780 & 0.0145 \\
\hline 4 & $*<0.02$ & $<0.0006$ & $<0.001$ & $<0.01$ & 0.0320 & $<0.02$ & 0.0395 & 0.0063 & $<0.002$ & $<0.008$ & 0.0765 & 0.0044 \\
\hline 5 & $<0.02$ & $<0.0006$ & $<0.001$ & $<0.01$ & $<0.006$ & $<0.02$ & 1.786 & 0.0066 & 0.0042 & $<0.008$ & 0.1024 & 0.0022 \\
\hline 6 & 0.1817 & $<0.0006$ & $<0.001$ & $<0.01$ & 0.0112 & $<0.02$ & 0.0842 & 0.0083 & 0.0045 & $<0.008$ & 0.0410 & 0.0227 \\
\hline 7 & $<0.02$ & $<0.0006$ & $<0.001$ & $<0.01$ & 0.0086 & 0.0857 & 0.9221 & 0.0025 & $<0.002$ & $<0.008$ & 0.0277 & 0.0030 \\
\hline 8 & 0.1722 & $<0.0006$ & $<0.001$ & 0.0279 & $<0.006$ & 0.0776 & 0.0129 & 0.0054 & $<0.002$ & $<0.008$ & 0.0234 & 0.0164 \\
\hline 9 & 0.0224 & $<0.0006$ & $<0.001$ & $<0.01$ & 0.0202 & 0.0301 & 0.4567 & 0.0023 & $<0.002$ & $<0.008$ & $<0.01$ & 0.3901 \\
\hline 10 & $<0.02$ & $<0.0006$ & $<0.001$ & $<0.01$ & $<0.006$ & $<0.02$ & 0.1489 & 0.0039 & 0.0033 & $<0.008$ & $<0.01$ & 0.0031 \\
\hline 11 & 0.1385 & $<0.0006$ & $<0.001$ & 0.0236 & 0.0553 & $<0.02$ & 0.0021 & 0.0032 & $<0.002$ & $<0.008$ & 0.0358 & 0.0039 \\
\hline 12 & 0.0899 & $<0.0006$ & $<0.001$ & $<0.01$ & $<0.006$ & 0.1192 & 0.0048 & 0.0091 & 0.0091 & $<0.008$ & 0.0501 & 0.0075 \\
\hline 13 & 0.1648 & $<0.0006$ & $<0.001$ & $<0.01$ & 0.0126 & 0.0466 & 0.0022 & 0.0022 & $<0.002$ & $<0.008$ & $<0.01$ & 0.0108 \\
\hline 14 & 0.1695 & $<0.0006$ & $<0.001$ & $<0.01$ & $<0.006$ & $<0.02$ & 0.0318 & 0.0039 & $<0.002$ & $<0.008$ & 0.0402 & 0.1245 \\
\hline 15 & 0.1699 & $<0.0006$ & $<0.001$ & 0.0256 & 0.0588 & 0.1255 & 1.113 & 0.0068 & 0.0091 & $<0.008$ & 0.0782 & 0.2092 \\
\hline 16 & 0.1843 & $<0.0006$ & $<0.001$ & 0.0238 & 0.0531 & 0.1290 & 1.882 & 0.0117 & 0.0094 & $<0.008$ & 0.0645 & 0.2900 \\
\hline 17 & 0.1995 & $<0.0006$ & $<0.001$ & 0.0211 & 0.0678 & 0.1199 & 1.879 & 0.0120 & 0.0074 & $<0.008$ & 0.0772 & 0.1845 \\
\hline 18 & 0.4588 & $<0.0006$ & $<0.001$ & 0.0248 & 0.0566 & 0.1174 & 1.764 & 0.0185 & 0.0090 & $<0.008$ & 0.0857 & 0.3689 \\
\hline 19 & 0.1677 & $<0.0006$ & $<0.001$ & 0.0237 & 0.0389 & 0.1055 & 1.777 & 0.0198 & 0.0081 & $<0.008$ & 0.1021 & 0.2999 \\
\hline 20 & 0.1721 & $<0.0006$ & $<0.001$ & 0.0255 & 0.0668 & 0.0732 & 1.785 & 0.0120 & 0.0095 & $<0.008$ & 0.9621 & 0.3441 \\
\hline 21 & 0.4521 & $<0.0006$ & $<0.001$ & 0.0243 & 0.0536 & 0.0192 & 1.684 & 0.0199 & 0.0098 & $<0.008$ & 0.8547 & 0.3882 \\
\hline 22 & 0.4639 & $<0.0006$ & $<0.001$ & 0.0229 & 0.0624 & 0.0758 & 1.958 & 0.0175 & 0.0085 & $<0.008$ & 0.1005 & 0.3119 \\
\hline 23 & 0.4544 & $<0.0006$ & $<0.001$ & 0.0231 & 0.0511 & $<0.02$ & 0.4567 & 0.0011 & $<0.002$ & $<0.008$ & $<0.01$ & 0.1165 \\
\hline 24 & 0.1056 & $<0.0006$ & $<0.001$ & $<0.01$ & $<0.006$ & $<0.02$ & 0.0351 & 0.0026 & 0.0029 & $<0.008$ & 0.0357 & 0.0581 \\
\hline 25 & 0.1022 & $<0.0006$ & $<0.001$ & $<0.01$ & $<0.006$ & 0.0245 & 0.0977 & 0.0078 & $<0.002$ & $<0.008$ & 0.0249 & 0.0668 \\
\hline 26 & 0.1347 & $<0.0006$ & $<0.001$ & $<0.01$ & $<0.006$ & $<0.02$ & 0.0662 & 0.0081 & $<0.002$ & $<0.008$ & $<0.01$ & 0.0740 \\
\hline 27 & 0.1301 & $<0.0006$ & $<0.001$ & 0.0266 & $<0.006$ & $<0.02$ & 0.0488 & 0.0023 & $<0.002$ & $<0.008$ & $<0.01$ & 0.0022 \\
\hline 28 & 0.0271 & $<0.0006$ & $<0.001$ & $<0.01$ & $<0.006$ & 0.1182 & 0.0771 & 0.0057 & $<0.0038$ & $<0.008$ & $<0.01$ & 0.0025 \\
\hline 29 & $<0.02$ & $<0.0006$ & $<0.001$ & $<0.01$ & $<0.006$ & $<0.02$ & 0.3552 & 0.0069 & $<0.002$ & $<0.008$ & $<0.01$ & 0.0023 \\
\hline 30 & 0.0271 & $<0.0006$ & $<0.001$ & $<0.01$ & $<0.006$ & $<0.02$ & 0.4111 & 0.0084 & $<0.002$ & $<0.008$ & $<0.01$ & 0.0021 \\
\hline 31 & $<0.02$ & $<0.0006$ & $<0.001$ & $<0.01$ & $<0.006$ & $<0.02$ & 0.0066 & 0.0046 & $<0.002$ & $<0.008$ & 0.0254 & 0.0047 \\
\hline 32 & 0.0271 & $<0.0006$ & $<0.001$ & $<0.01$ & 0.0334 & 0.0311 & 0.0274 & 0.0041 & 0.0066 & $<0.008$ & 0.0261 & 0.0033 \\
\hline 33 & $<0.02$ & $<0.0006$ & $<0.001$ & $<0.01$ & $<0.006$ & $<0.02$ & 0.0029 & 0.0039 & 0.0054 & $<0.008$ & $<0.01$ & 0.0098 \\
\hline$* * 34$ & 0.4261 & $<0.0006$ & $<0.001$ & 0.0250 & 0.0575 & $<0.02$ & 0.0061 & 0.0011 & $<0.002$ & $<0.008$ & $<0.01$ & 0.0018 \\
\hline
\end{tabular}

${ }^{*}<=$ detection limit; ${ }^{* *}$ : Nile water in Ismailia Canal. 
The change in the concentrations of salinity (as TDS) and major ions is illustrated in Figure 6(a), Figure 6(b). The high increase in the salinity of groundwater is associated with the higher content of $\mathrm{Cl}^{-}, \mathrm{SO}_{4}^{2-}, \mathrm{Na}^{+}, \mathrm{Ca}^{2+}$, and $\mathrm{Mg}^{2+}$ ions. The higher concentrations of such constituents are recorded for the wells 2 , $7,20,21$, and 22 drilled in and around the cultivated lands.

The nitrate content in groundwater varies considerably (Table 2). An overabundance amount of nitrate content that exceed the maximum contaminant levels of $10 \mathrm{mg} / \mathrm{L}$ for nitrate [36] is recorded in $45 \%$ of wells. The higher concentrations of $\mathrm{NO}_{3}^{-}$ions (>47 mg/L) are recorded in the wells 7, 15, 16, 17, 18, 19, 20, and 22 located in and around the cultivated lands (Figure 6(c)).

Low concentrations of phosphate ions are detected in the groundwater, ranging from a fraction of $\mathrm{mg} / \mathrm{L}$ to $0.72 \mathrm{mg} / \mathrm{L}$, which is less than the maximum contaminant level of $1.0 \mathrm{mg} / \mathrm{L}$ for phosphate [37]. The concentrations of nutrients in Ismailia Canal water are generally low attaining $6.24 \mathrm{mg} / \mathrm{L}$ for nitrate and 0.02 $\mathrm{mg} / \mathrm{L}$ for phosphate (Table 2).

Contents of $\mathrm{Cd}, \mathrm{Co}$ and $\mathrm{Pb}$ elements in groundwater of the aquifer are less than the detection limits of the used instruments for analyses (Table 3). The concentrations of $\mathrm{Ni}, \mathrm{Cr}$, and $\mathrm{Fe}$ elements are below the detection limits in about $57 \%$ of groundwater samples. And the rest of samples show concentrations vary from $0.0033 \mathrm{mg} / \mathrm{L}$ to $0.0098 \mathrm{mg} / \mathrm{L}$ for $\mathrm{Ni}$, from $0.0211 \mathrm{mg} / \mathrm{L}$ to $0.0279 \mathrm{mg} / \mathrm{L}$ for $\mathrm{Cr}$ and from $0.0311 \mathrm{mg} / \mathrm{L}$ to $0.1290 \mathrm{mg} / \mathrm{L}$ for Fe.

The contents of $\mathrm{Al}$ element in $79 \%$ of groundwater samples range from 0.0271 $\mathrm{mg} / \mathrm{L}$ to $0.4639 \mathrm{mg} / \mathrm{L}$, while in the rest of samples show $\mathrm{Al}$ content that is less than the detection limit. Concentrations of $\mathrm{Cu}$ element in $48 \%$ of groundwater samples and water of Ismailia Canal are below the detection limit of the used instruments, while the concentrations in the rest of samples vary between 0.0112 $\mathrm{mg} / \mathrm{L}$ and $0.0678 \mathrm{mg} / \mathrm{L}$.

About $44 \%$ of groundwater samples and water of Ismailia Canal contain V concentrations below the detection limit, and the rest of samples show concentrations ranging from $0.0234 \mathrm{mg} / \mathrm{L}$ to $0.9621 \mathrm{mg} / \mathrm{L}$. Without exception all

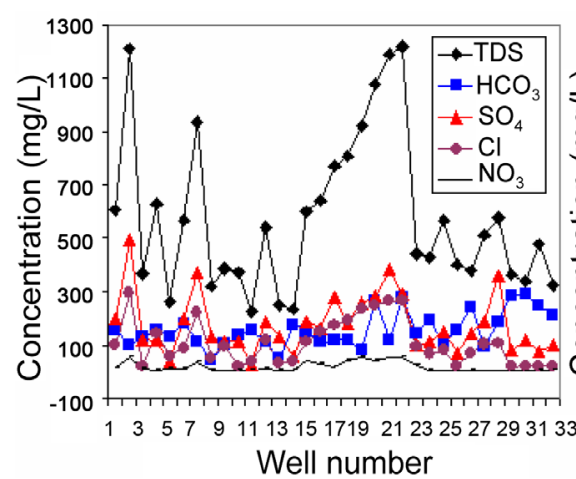

(a)

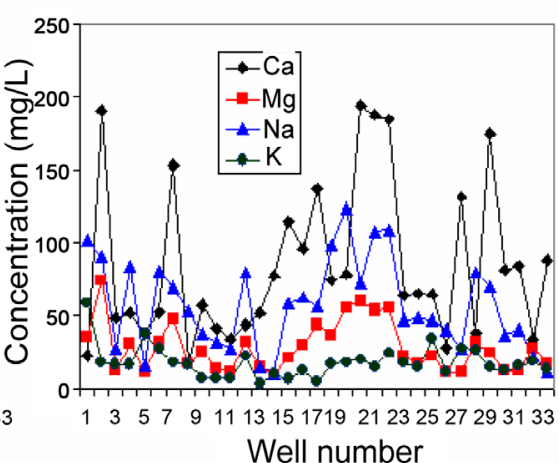

(b)

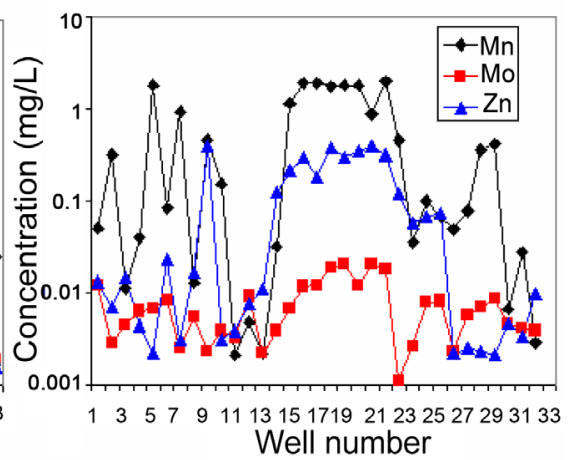

(c)

Figure 6. Major ion composition, TDS, nitrate, Mn, Mo, and Zn of groundwater in the Quaternary aquifer, Northeast Cairo area, Egypt. (a) TDS and Major anions; (b) Major cations; (c) Trace elements. 
groundwater samples and Ismailia Canal water show measurable concentrations of Mn, Mo, and Zn elements (Table 3). The higher concentrations are recorded for groundwater samples 5, 15, 16, 17, 18, 19, 20, 21, and 22 (Figure 6(c)).

The TDS, major ions, nitrate, Mn, Mo, and $\mathrm{Zn}$ elements are found to increase towards the cultivated lands parallel to the direction of groundwater flow. The heterogeneity in the chemical compositions of groundwater is most probably related to the variation in the geologic and recharge conditions.

\section{Discussion}

\subsection{Aquifer Geometry and Groundwater Movement}

In the study area, the Quaternary aquifer is formed of heterogeneous materials of yellowish brown, medium to coarse-grained sands with occasional soft and brown clay lenses and few amounts of gravels and calcareous materials (Figure 4(a), Figure 4(b)). The Quaternary aquifer is overlain by a semi-permeable Nile silty layer (aquitard) of Holocene age, rendering the aquifer under semi-confining conditions. The Nile silt layer is composed of heterogeneous and anisotropic materials (silt, clay and sand). It has a thickness that ranges from $15 \mathrm{~m}$ adjacent to Ismailia Canal due east to $5 \mathrm{~m}$ in the western part of the study area. The average hydraulic conductivity of the Nile silt layer ranges from 0.005 to $0.05 \mathrm{~m} / \mathrm{day}$ [6]. The depth of water below the land surface is shallow, ranging from $2.5 \mathrm{~m}$ near Ismailia Canal due west and $4.3 \mathrm{~m}$ at $\mathrm{Al}$ Marg area due east (Figure 5(a)).

The distribution of hydraulic heads in the aquifer is shown in Figure 5(b). The groundwater levels range from about $12.8 \mathrm{~m}$ above mean sea level (MSL) under the cultivated lands to more than $14.9 \mathrm{~m}$ (MSL) westwards and $16.3 \mathrm{~m}$ (MSL) southwestwards in the urban areas. The groundwater approximately moves from all directions towards the cultivated lands, with a hydraulic gradient varies between 0.0041 and 0.00028 with an average of 0.0017 . The piezometric surface contour map shows the existence of a groundwater cone of depression, which has originated from the heavy pumping of water to meet agricultural demands. Big separation between contour lines in the western part of the area implies more permeable aquifer materials, and the vice versa in the eastern part of the area. Most probably, the irregularity of contour lines is originated due the heterogeneity in the aquifer materials and the change in aquifer hydraulic conductivity. The aquifer hydraulic conductivity ranges from $62 \mathrm{~m} /$ day to 100 $\mathrm{m} /$ day [7].

Based on the directions of flow lines (Figure 5(b)), the aquifer receives recharge from east and northeast directions (i.e. from Ismailia Canal), from the southern direction (i.e. from the Nile aquifer system) and from the west direction (most probably from the Miocene aquifer).

\subsection{Hydrogeochemical Signature}

The hydrochemical parameters and ionic ratios are used to throw light on some 
chemical processes of the groundwater interactions and give indications about the groundwater evolution. The relationship between $\mathrm{Cl}^{-}$and $\mathrm{Na}^{+}$ions (Figure 7 (a)) indicates the effect of water-rock interaction processes on the groundwater chemistry. About $21 \%$ of groundwater samples and water of Ismailia Canal lie directly on the isometric dissolution line and have equal concentrations of $\mathrm{Na}^{+}$ and $\mathrm{Cl}^{-}$ions, indicating the dissolution of halite mineral. The groundwater samples (33\% of samples) that are located above the dissolution line indicate the dominance of $\mathrm{Na}^{+}$over $\mathrm{Cl}^{-}$and may suggest the effect of silicate weathering and natural softening. The rest of samples (i.e. $46 \%$ of samples) which lie below the dissolution line show the dominance of $\mathrm{Cl}^{-}$over $\mathrm{Na}^{+}$and indicate the influence of reverse softening.

The distribution of the ionic ratios; $\mathrm{Na}^{+} / \mathrm{Cl}^{-}, \mathrm{Ca}^{2+} / \mathrm{Cl}^{-}, \mathrm{Mg}^{2+} / \mathrm{Cl}^{-}, \mathrm{SO}_{4}^{2-} / \mathrm{Cl}^{-}$ and $\mathrm{K}^{+} / \mathrm{Cl}^{-}$versus $\mathrm{Cl}^{-}$ions indicates the presence of two main groups of waters that are affected by two different evolutionary trends (Figures $7(\mathrm{~b})-(\mathrm{f})$ ). The

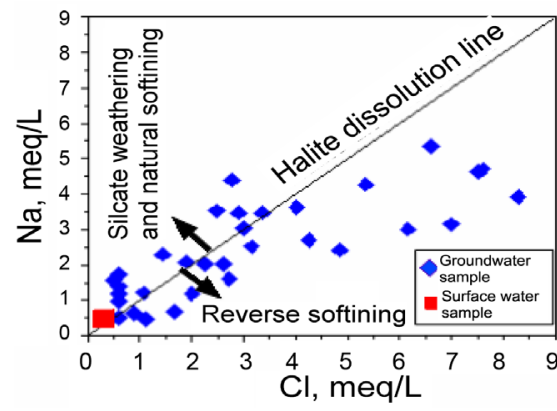

(a)

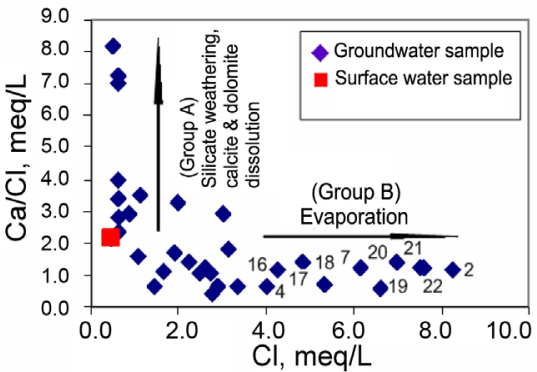

(c)

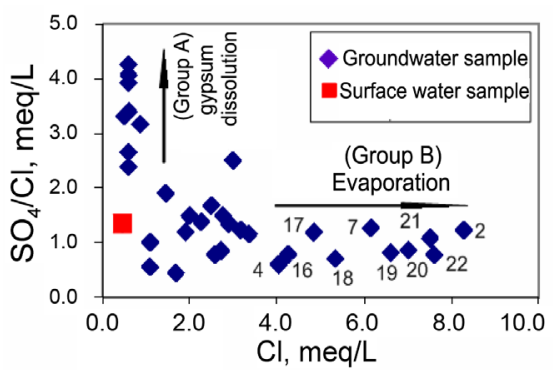

(e)

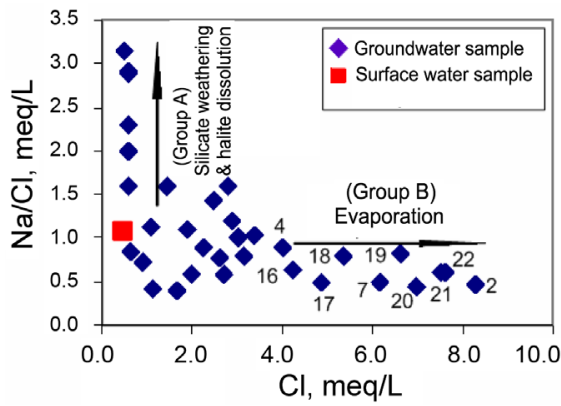

(b)

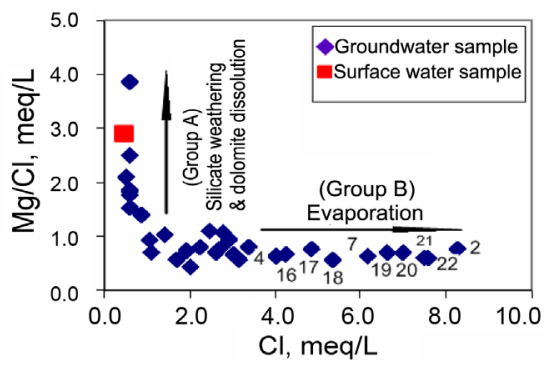

(d)

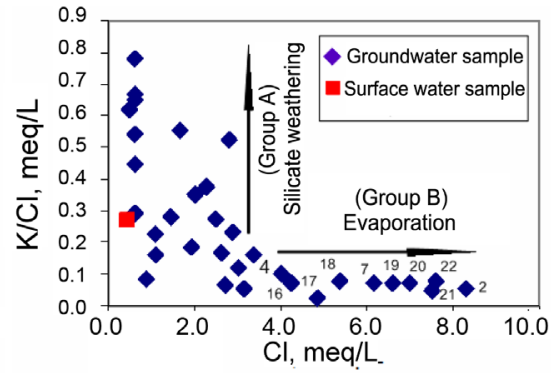

(f)

Figure 7. Trends of distributions of ionic ratios with respect to $\mathrm{Cl}$ content in the Quaternary aquifer, Northeast Cairo area, Egypt. 
first group (group A) is represented by the majority of water samples having low salinity, ranging from $225 \mathrm{mg} / \mathrm{L}$ and $610 \mathrm{mg} / \mathrm{L}$. The second one (group B) is represented by the groundwater samples $2,4,7,16,17,18,19,20,21$, and 22 having a relatively high salinity between $630 \mathrm{mg} / \mathrm{L}$ and $1220 \mathrm{mg} / \mathrm{L}$. The chemistry of low saline groundwater (group A) seems to be controlled by the natural geochemical factors such as silicates weathering and dissolution of halite, calcite, dolomite and gypsum minerals. Such processes increase the contents of $\mathrm{Na}^{+}$, $\mathrm{Ca}^{2+}, \mathrm{Mg}^{2+}, \mathrm{SO}_{4}^{2-}$ and $\mathrm{K}^{+}$ions in the groundwater, meanwhile the increase in $\mathrm{Cl}^{-}$ion is insignificant. On the other hand, the chemistry of the high saline groundwater (group B) is primarily controlled by evaporation, where the chloride content increases without a significant increase in the related ionic ratios. This may refer to the contribution to the Quaternary aquifer from the evaporated surface effluents, especially in the cultivated and industrial areas.

The plot of $\mathrm{NO}_{3}^{-}$versus $\mathrm{Cl}^{-}$ions (Figure 8(a)) indicates that the concentration of $\mathrm{NO}_{3}^{-}$ions increase linearly by increasing the $\mathrm{Cl}^{-}$ions with correlation coefficient $(\mathrm{R}=0.88)$. Similar trends are observed from the plots of $\mathrm{Mn}, \mathrm{Mo}$ and $\mathrm{Zn}$ elements against $\mathrm{Cl}^{-}$ions where the concentrations of these elements increase as the $\mathrm{Cl}^{-}$ions increase $(0.59<\mathrm{R}<0.69)$ (Figures $\left.8(\mathrm{~b})-(\mathrm{d})\right)$. The high nitrate, chloride, manganese, molybdenum and zink contents in groundwater belonging to group B water are most probably due to contamination of recharge to the aquifer by deteriorated septic systems, industrial waste water and agricultural drainage.

\subsection{Geochemistry of Stable Isotopes}

Stable isotopic data measured for the groundwater and Ismailia Canal water are
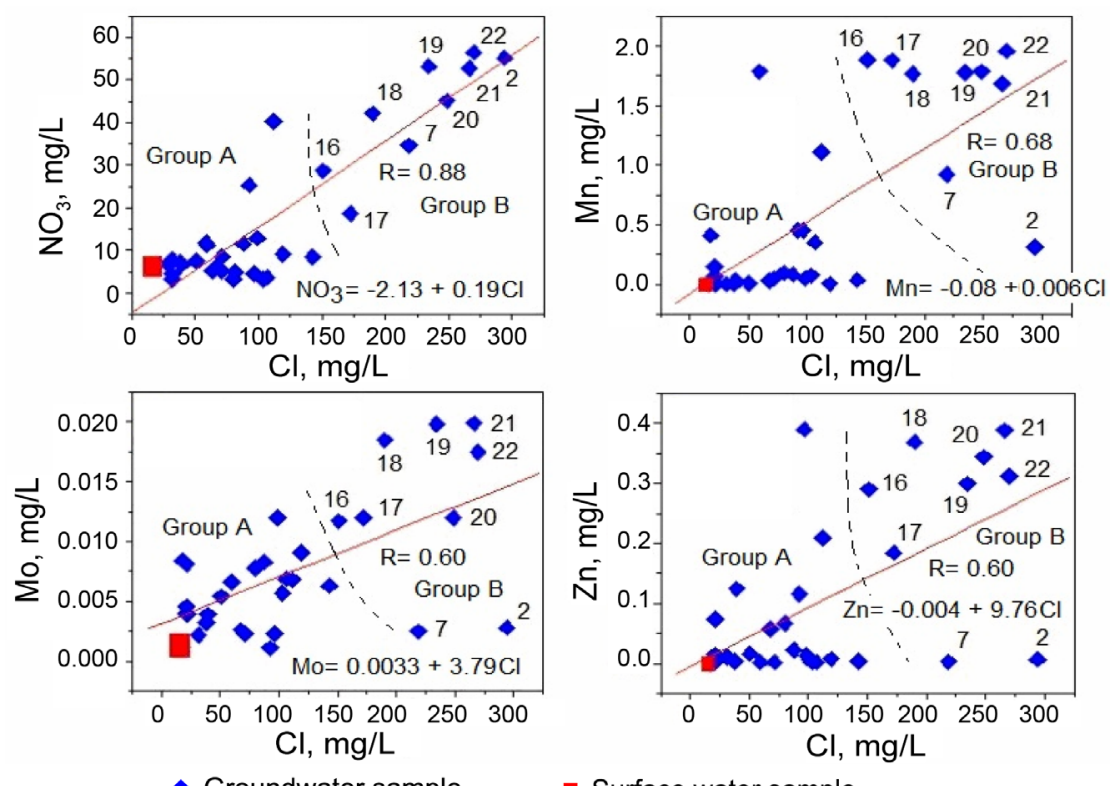

Figure 8. Relations between the concentrations of $\mathrm{NO}_{3}, \mathrm{Mn}, \mathrm{Mo}$ and $\mathrm{Zn}$ vs. $\mathrm{Cl}$ in the Quaternary aquifer, Northeast Cairo area, Egypt. 
listed in Table 2. The $\delta$ values vary greatly in the Quaternary aquifer, ranging from $-0.19 \%$ to $5.16 \%$ for oxygen- 18 and from $3.4 \%$ to $34 \%$ or deuterium. There being a general tendency of increase of $\delta$ values toward the west (under the cultivated land) parallel to the direction of flow. The heterogeneous isotopic contents in the groundwater of the aquifer may suggest the contribution from others water resources, either surface or subsurface waters.

The $\delta^{18} \mathrm{O}$ and $\delta^{2} \mathrm{H}$ values of water samples are plotted on a classical $\delta^{18} \mathrm{O}$ and $\delta^{8} \mathrm{H}$ diagram (Figure 9(a)). The isotopic compositions of the old Nile water [38], irrigation return flow [39] and Miocene aquifer [40] are included in the diagram for comparison. The old Nile water is a term denoting to the water that is recharged to the Nile aquifer system from the Nile floods occurring before the construction of Aswan High Dam of Egypt in 1963 [41]. Therefore, it is depleted in its isotopic composition comparing with that of the modern Nile water after the construction of the High Dam.

The distribution manner of the isotopic values of groundwater samples with respect to the WMWL (world meteoric water line) suggests the meteoric origin of groundwater. The values of $\delta^{18} \mathrm{O}$ significantly correlate with $\delta^{8} \mathrm{H}$ values, and the best fit equation is reported as $\delta^{2} \mathrm{H}=6.24 \delta^{18} \mathrm{O}+5.24 \%$, with correlation coefficient attaining 0.95 . Here the regression line indicates the potential influence

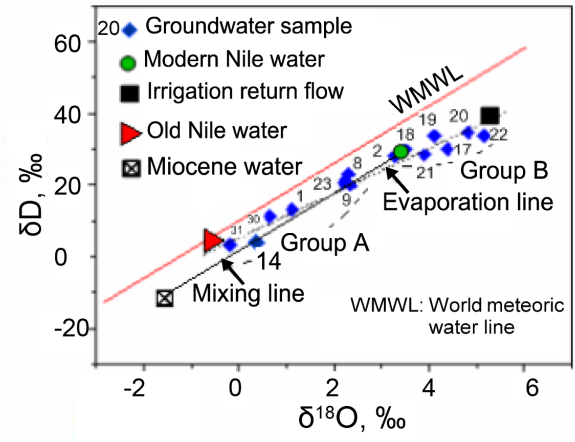

(a)

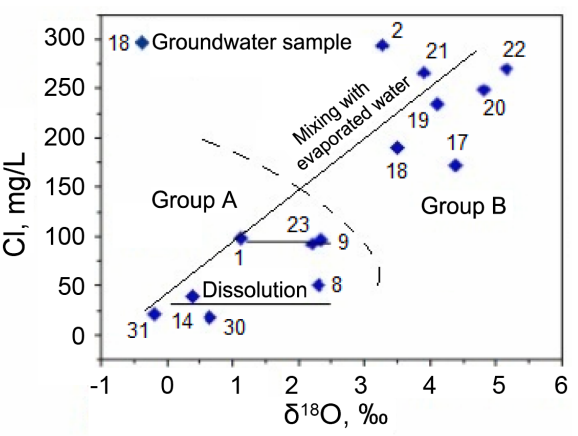

(b)

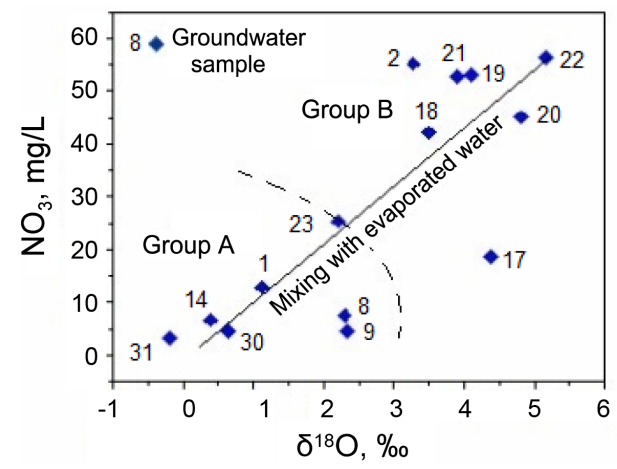

(c)

Figure 9. Binary relations. (a) Plot of $\delta^{18} \mathrm{O}$ versus $\delta^{2} \mathrm{H}$; (b) Plot of $\delta^{18} \mathrm{O}$ versus $\mathrm{Cl}$, and (c) Plot of $\delta^{18} \mathrm{O}$ versus $\mathrm{NO}_{3}$. The Group $\mathrm{B}$ groundwater has enriched isotopic, $\mathrm{Cl}$ and $\mathrm{NO}_{3}$ contents comparing with Group A groundwater. 
of evaporation, where the slope and intercept are found to be less than those of the WMWL described by the equation $\delta^{2} \mathrm{H}=8 \delta^{18} \mathrm{O}+10 \%$ [42]. The evaporation trend is greatly consistent with the mixing in the aquifer between the old Nile water and the surplus water of irrigation (Figure 9(a)).

The aforementioned two groups of waters (groups A and B) are also distinguished on the $\delta^{18} \mathrm{O}-\delta^{2} \mathrm{H}$ diagram (Figure 9). The first group (group A) includes the groundwater samples $1,2,8,9,14,23,30$, and 31 and has isotopic composition ranging from $-0.19 \%$ to $3.28 \%$ for oxygen- 8 and from $3.4 \%$ to $27.99 \%$ for deuterium. The groundwater of this group is less affected by evaporation. The relative depletion in $\delta^{18} \mathrm{O}$ and $\delta^{2} \mathrm{H}$ values comparing with the modern Nile water refer to the contribution from the old Nile water and Miocene water that are depleted in stable isotopes.

The second group (group B) comprises the water samples from the wells 17, $18,19,20,21$, and 22 scattered in the cultivated land around the industrial areas. The groundwater belonging to this group has enriched isotopic content ranging from $3.5 \%$ to $5.16 \%$ or oxygen-8 and from $28.43 \%$ to $33.91 \%$ or deuterium. The more enrichment of $\delta^{18} \mathrm{O}$ and $\delta^{2} \mathrm{H}$ values of the groundwater indicates the contribution to the aquifer from surface water sources (such as Ismailia Canal and surplus water of irrigations) having enriched stable isotopic contents.

Figure 9(b), Figure 9(c) illustrates plots of $\delta^{18} \mathrm{O}$ against the contents of $\mathrm{Cl}^{-}$ and $\mathrm{NO}_{3}{ }^{-}$ions in the Quaternary aquifer. Here the trends appear to be that the $\mathrm{Cl}^{-}$and $\mathrm{NO}_{3}^{-}$contents increase as the $\delta^{18} \mathrm{O}$ increases, which indicate the mixing with evaporated surface water. A substantial degree of mixing with surplus water of irrigation is observed for the groundwater belonging to group $\mathrm{B}$, where $\delta^{18} \mathrm{O}, \mathrm{Cl}^{-}$and $\mathrm{NO}_{3}{ }^{-}$contents are enriched more with respect to that of group A. The high concentrations of chloride and nitrate ions support the hypothesis that the aquifer receives contaminants recharge from the surface. Sources containing nitrate and chloride exist in the area and commonly linked to the nitrogen-based fertilizers used in agriculture, sewage and industrial liquid wastes.

\subsection{Groundwater Quality Assessment}

\subsubsection{Quality of Groundwater for Drinking}

Table 4 shows the maximum permissible limits (MPL) of inorganic constituents in water used for drinking and domestic uses [28] [29], also included are the groundwater samples having concentrations values that exceed these limits. About $66.6 \%$ of wells in the study area yield water that is unsuitable for drinking because of the high $\mathrm{pH}, \mathrm{TDS}, \mathrm{Cl}^{-}, \mathrm{SO}_{4}{ }^{2-}, \mathrm{Mn}, \mathrm{Al}$ and $\mathrm{NO}_{3}{ }^{-}$contents that exceed the MPL. Also, 15\% of wells (Nos. 2, 19, 20, 21 and 22) produce unsuitable water for drinking because of the high contents of nitrate that exceed the MPL.

The computed nitrate pollution index, NPI (Table 5) reveals that the major part of groundwater $(69.69 \%)$ extracted from the area is free from nitrate pollution (NPI $<0)$. The groundwater samples 7, 16, and 23 are slightly polluted with 
Table 4. Groundwater samples exceeding the maximum permissible limits of drinking and domestic purposes.

\begin{tabular}{|c|c|c|c|c|c|c|c|c|c|c|c|c|c|c|c|c|c|c|}
\hline \multirow{2}{*}{ Parameter } & \multicolumn{12}{|c|}{ Chemical constituents affecting the taste and domestic uses } & \multicolumn{6}{|c|}{$\begin{array}{l}\text { Chemical constituents affecting the hu- } \\
\text { man health }\end{array}$} \\
\hline & $\mathrm{pH}$ & TDS & $\mathrm{TH}$ & $\mathrm{Na}$ & $\mathrm{Ca}$ & $\mathrm{Mg}$ & $\mathrm{Cl}$ & $\mathrm{SO}_{4}$ & $\mathrm{Fe}$ & $\mathrm{Mn}$ & $\mathrm{Cu}$ & $\mathrm{Zn}$ & $\mathrm{Al}$ & $\mathrm{Pb}$ & $\mathrm{Cd}$ & $\mathrm{Cr}$ & $\mathrm{Ni}$ & $\mathrm{No}_{3}$ \\
\hline $\begin{array}{l}\text { Maximum } \\
\text { permissible } \\
\text { limit }\end{array}$ & $6.5-8.5$ & 1000 & 500 & 200 & 200 & 150 & 250 & 250 & 0.3 & 0.4 & 2.0 & 3.0 & 0.2 & 0.01 & 0.003 & 0.05 & 0.02 & 45 \\
\hline $\begin{array}{l}\text { Sample } \\
\text { exceed }\end{array}$ & $\begin{array}{c}1,8 \\
10,25 \\
26,27 \\
30,31 \\
33\end{array}$ & $\begin{array}{l}2,20 \\
21,22\end{array}$ & - & - & - & - & $\begin{array}{l}2, \\
21, \\
22\end{array}$ & $\begin{array}{c}7, \\
17 \\
19,20, \\
21 \\
22\end{array}$ & - & $\begin{array}{c}5,7, \\
9,15, \\
16,17, \\
18,19, \\
20,21, \\
22,23, \\
30\end{array}$ & - & - & $\begin{array}{l}18, \\
21, \\
22, \\
23\end{array}$ & - & - & - & - & $\begin{array}{c}2,19 \\
20,21 \\
22\end{array}$ \\
\hline
\end{tabular}

nitrate $(0<\mathrm{NPI}<1)$ and the groundwater samples $2,15,18,19,20,21$, and 22 are moderately polluted $(1<\mathrm{NPI}<2)$. The Quaternary aquifer in the area beneath the cultivated lands and around the industrial zone is the more vulnerable to pollution with nitrate (Figure 10(a)).

The calculated water quality index values, WQI (Table 5) vary between 27.80 and 137.28, and accordingly the groundwater quality can be put into three classes, excellent $(60.61 \%)$, good $(18.18 \%)$ and poor $(21.21 \%)$. The poor quality of groundwater in the area is mainly due to the higher values of total hardness, $\mathrm{pH}, \mathrm{SO}_{4}{ }^{2-}, \mathrm{Mn}, \mathrm{Al}$, and $\mathrm{NO}_{3}{ }^{-}$. Figure $10(\mathrm{~b})$ indicates that the areas located under the northern and south-eastern parts of the cultivated and industrial zones have a poor quality of groundwater $(\mathrm{WQI}<101)$.

\subsubsection{Quality of Groundwater for Domestic Uses}

The water quality index (WQI) values calculated for the groundwater samples (Table 5) range from 31.11 to 160.42 . They reveal that about $54.55 \%, 18.18 \%$ and $22.27 \%$ of the groundwater are excellent, good and poor, respectively. The higher WQI values are mainly originated due to the higher contents of manganese, magnesium, aluminum, $\mathrm{pH}$ and total hardness. The poor water concentrates in the areas beneath the northern and southeastern parts of the cultivated lands (Figure 10(c)).

\subsubsection{Quality of Groundwater for Irrigation Uses}

The water quality index (WQI) is calculated only for the groundwater extracted from the wells 2, 7, 9 and 29, which are used for irrigation in the study area. Based on the WQI values (Table 5), the water of wells 7, 29, and 2 is suitable for irrigation with slight and moderate degree of restriction on use, while the water of well 9 and Ismailia Canal is suitable without restriction.

\section{Summary and Conclusions}

The Quaternary aquifer is the second largest source of potable water in the densely populated area of Northeast Cairo, Egypt. The area contains several 
Table 5. Nitrate pollution index (NPI) and water quality index (WQI) for drinking, domestic and irrigation uses.

\begin{tabular}{|c|c|c|c|c|c|c|c|c|}
\hline \multirow{2}{*}{$\begin{array}{l}\text { Water } \\
\text { point }\end{array}$} & \multicolumn{2}{|c|}{ Pollution with nitrate } & \multicolumn{2}{|c|}{ Drinking water } & \multicolumn{2}{|c|}{ Domestic } & \multicolumn{2}{|c|}{ Irrigation } \\
\hline & NPI & Class & $\begin{array}{l}\text { WQI, } \\
\text { Drinking }\end{array}$ & Class & $\begin{array}{c}\text { WQI, } \\
\text { domestic }\end{array}$ & Class & $\begin{array}{l}\text { WQI, } \\
\text { irrigation }\end{array}$ & $\begin{array}{l}\text { Degree of } \\
\text { restriction on use }\end{array}$ \\
\hline 1 & -0.36 & Unpolluted & 39.66 & Excellent & 48.64 & Excellent & 742.77 & - \\
\hline 2 & 1.76 & Moderate & 82.17 & Good & 101.57 & Poor & 309.16 & Moderate \\
\hline 3 & -0.41 & Unpolluted & 27.80 & Excellent & 33.77 & Excellent & 226.65 & - \\
\hline 4 & -0.57 & Unpolluted & 33.87 & Excellent & 37.24 & Excellent & 233.08 & - \\
\hline 5 & -0.44 & Unpolluted & 81.53 & Good & 97.00 & Good & 466.37 & - \\
\hline 6 & -0.42 & Unpolluted & 41.90 & Excellent & 51.29 & Good & 370.77 & - \\
\hline 7 & 0.73 & Light & 85.54 & Good & 108.57 & Poor & 289.79 & Slight \\
\hline 8 & -0.62 & Unpolluted & 34.09 & Excellent & 39.77 & Excellent & 227.19 & - \\
\hline 9 & -0.77 & Unpolluted & 44.81 & Excellent & 53.37 & good & 119.04 & None \\
\hline 10 & -0.74 & Unpolluted & 31.54 & Excellent & 38.31 & Excellent & 118.17 & - \\
\hline 11 & -0.64 & Unpolluted & 26.35 & Excellent & 25.56 & Excellent & 108.46 & - \\
\hline 12 & -0.54 & Unpolluted & 39.49 & Excellent & 46.37 & Excellent & 310.88 & - \\
\hline 13 & -0.60 & Unpolluted & 30.47 & Excellent & 38.18 & Excellent & 70.94 & - \\
\hline 14 & -0.67 & Unpolluted & 29.29 & Excellent & 32.07 & Excellent & 148.11 & - \\
\hline 15 & 1.02 & Moderate & 84.85 & Good & 97.37 & Good & 128.19 & - \\
\hline 16 & 0.44 & Light & 109.50 & Poor & 128.39 & Poor & 198.50 & - \\
\hline 17 & -0.07 & Unpolluted & 116.70 & Poor & 143.61 & Poor & 114.99 & - \\
\hline 18 & 1.11 & Moderate & 115.32 & Poor & 133.80 & Poor & 261.11 & - \\
\hline 19 & 1.66 & Moderate & 115.67 & Poor & 134.76 & Poor & 286.86 & - \\
\hline 20 & 1.26 & Moderate & 123.95 & Poor & 144.31 & Poor & 314.98 & - \\
\hline 21 & 1.64 & Moderate & 131.05 & Poor & 157.49 & Poor & 263.09 & - \\
\hline 22 & 1.82 & Moderate & 137.28 & Poor & 160.42 & Poor & 370.72 & -- \\
\hline 23 & 0.27 & Light & 57.78 & Good & 64.53 & Good & 248.58 & - \\
\hline 24 & -0.69 & Unpolluted & 32.46 & Excellent & 37.20 & Excellent & 204.27 & - \\
\hline 25 & -0.84 & Unpolluted & 37.23 & Excellent & 45.93 & Excellent & 447.61 & - \\
\hline 26 & -0.76 & Unpolluted & 28.85 & Excellent & 33.56 & Excellent & 160.49 & - \\
\hline 27 & -0.74 & Unpolluted & 39.64 & Excellent & 45.29 & Excellent & 375.00 & - \\
\hline 28 & -0.84 & Unpolluted & 36.87 & Excellent & 46.49 & Excellent & 364.72 & - \\
\hline 29 & -0.82 & Unpolluted & 57.81 & Good & 79.00 & Good & 238.20 & Slight \\
\hline 30 & -0.78 & Unpolluted & 41.11 & Excellent & 48.28 & Excellent & 182.26 & - \\
\hline 31 & -0.84 & Unpolluted & 29.19 & Excellent & 34.96 & Excellent & 223.31 & - \\
\hline 32 & -0.58 & Unpolluted & 28.83 & Excellent & 31.11 & Excellent & 257.71 & - \\
\hline 33 & -0.66 & Unpolluted & 29.93 & Excellent & 33.46 & Excellent & 191.96 & - \\
\hline 34 & -0.69 & Unpolluted & 32.59 & Excellent & 34.49 & Excellent & 83.20 & None \\
\hline
\end{tabular}




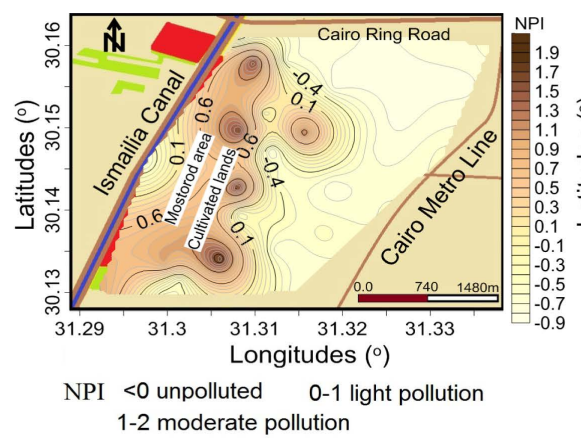

(a)

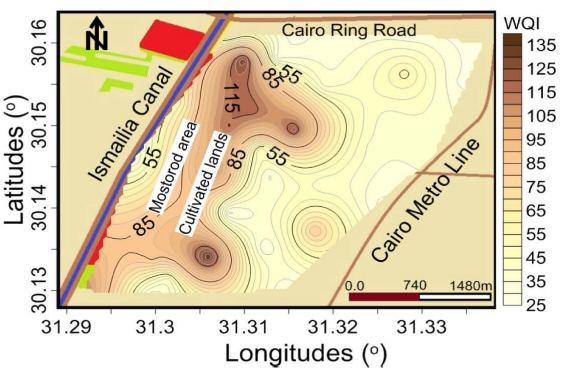

WQI for drinking $<50$ excellent $50-100$ good 101-200 poor

(b)

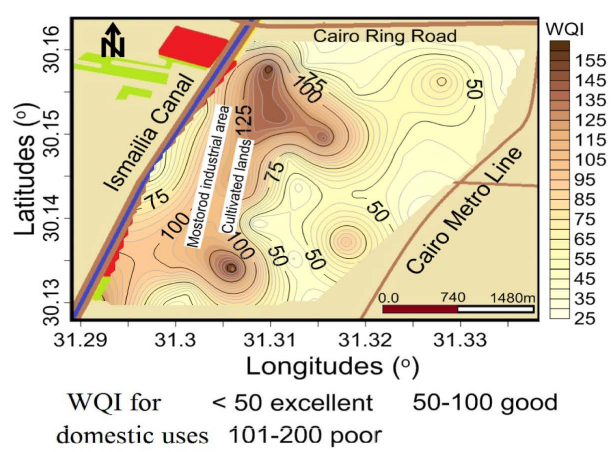

(c)

Figure 10. Maps showing the distribution of water quality indices; (a) nitrate pollution index; (b) water quality index for drinking and (c) water quality index for domestic purposes, the Quaternary aquifer, Northeast Cairo area, Egypt.

industrial facilities, and it has been selected to accommodate a number of new oil refinery units. Information dealing with the groundwater conditions in the area is very scarce.

This work presented groundwater baseline data that is vital and necessary before starting the operation of the new industrial projects. Geochemistry of the groundwater was investigated using an integrated approach including the hydrogeological, hydrochemical and isotopic tools. The relation between surface water and groundwater bodies was explored. The effects of natural and anthropogenic factors on the chemistry of groundwater were detected. The water quality indices were determined to assess quality of groundwater for different uses.

The Quaternary aquifer is mainly formed of sands, gravels with clay lenses and carbonaceous materials. The groundwater is shallow and exists under semi confining conditions. The direction of groundwater movement is towards the cultivated and industrial areas. The groundwater has alkaline nature $(7.5<\mathrm{pH}<$ 9.3) with salinity (as TDS) ranging between $225.6 \mathrm{mg} / \mathrm{L}$ and $1219 \mathrm{mg} / \mathrm{L}$. The contents of TDS and major ions vary greatly in the aquifer and generally increase towards the cultivated area parallel to the direction of groundwater flow. Overabundance amounts of nitrate contents $(<47 \mathrm{mg} / \mathrm{L})$ are recorded for many wells drilled in and around the cultivated area, while low concentrations of phosphate ions, ranging from a fraction of $\mathrm{mg} / \mathrm{L}$ to $0.72 \mathrm{mg} / \mathrm{L}$, are detected. 
Most groundwater samples show high levels of $\mathrm{Mn}$ and $\mathrm{Al}$ elements.

Two water groups showing two different evolutionary trends in the aquifer are distinguished from the relations between the hydrochemical and stable isotopic $\left(\delta^{18} \mathrm{O}\right.$ and $\left.\delta^{2} \mathrm{H}\right)$ parameters. The chemical quality of groundwater is affected by both the natural processes (weathering, dissolution and ion exchange) and human factors (agricultural and industrial activities). High levels of nitrate, manganese and aluminum that exceed the maximum permissible limits for drinking purpose are recorded in some sites. The calculated nitrate pollution index (NPI) reveals that about $30.30 \%$ of groundwater is polluted with nitrate, and therefore, it is unsuitable for drinking. The contamination is related to the extensive use of fertilizers for agriculture and the leakage of wastewater from improper sewage system. Moreover, the water quality indices (WQI) reveal that about $21.21 \%$ and $27.21 \%$ of groundwater, respectively, are classified as poor water for human consumption and domestic uses. The poor groundwater (the contaminated water) concentrates in the aquifer under and around the cultivated area and industrial zone as indicated from the NPI and WQI distribution maps.

The poor groundwater in the area should be treated before human consumption to exclude the concentrations of nitrate and others trace elements. The releases of wastewater from the industrial areas into sewage systems should be under control and monitored periodically. Regular observation of groundwater quality for drinking is strictly required. The improper sewage systems in some places in the urban areas must be fixed.

\section{References}

[1] Abu Zeid, M.A. and Rady, M.A. (1992) Water Resources Management and Policies in Egypt. In: Country Experiences with Water Resources Management: Economic, Technical and Environmental Issues, World Bank Technical Paper, Washington DC, 93-101.

[2] Attia, F.A. (1999) Water and Development in Greater Cairo (Egypt). Afers Internationals, 45-46, 81-102.

[3] El Arabi, N. (2012) Environmental Management of Groundwater in Egypt via Artificial Recharge Extending the Practice to Soil Aquifer Treatment (SAT). International Journal of Environment and Sustainability, 1, 66-82. https://doi.org/10.24102/ijes.v1i3.91

[4] Ban, J., Arellano, J.L., Alawami, A., Aguilera, R.F. and Tallet, M. (2016) World Oil Outlook 2016. OPEC A-1010, Vienna, Austria, 394.

[5] Korany, E.A. and Abdel Aal, M.E. (1986) Groundwater Response in the Urban Sectors of Cairo Environs, Egypt. Hydrological Processes and Water Management in Urban Areas (Proceedings of the Duisberg Symposium), IAHS Publ. No. 198, Duisberg, Germany, April 1990, 429-436.

[6] Shahin, M.M.A. (1990) Impacts of Urbanization of the Greater Cairo Area on the Groundwater in the Underlying Aquifer. Hydrological Processes and Water Management in Urban Areas (Proceedings of the Duisberg Symposium), IAHS Publ. No. 198, Duisberg, Germany, April 1990, 243-248.

[7] Eweida, E.A., Fayed, L.A. and Kotb, E.A. (1992) Hydrogeological Studies of El-Qalag and El-Khosus Wastewater Pumping Stations-Greater Cairo. Geology of 
the Arab World, Cairo University, Cairo, 179-193.

[8] Environics (2010) EIA Study for Greater Cairo Metro Line No. 4 Phase 1-Final Report. National Authority for Tunnel, 297.

[9] Ezz El-Deen, H.M. (1993) Sedimentlogical and Geophysical Studies of Heliopolis Basin, Cairo-Ismailia Desert Road, and Their Applications, Egypt. M.Sc. Thesis, Ain Shams University, Cairo, Egypt.

[10] El-Sayed, S.A., Ezz El Din, M.R. and Deyab, M.E. (2011) Hydrogeological Investigations of the Quaternary Aquifer in the Northern Part of El-Sharkia Governorate, Egypt. Isotope and Radiation Research, Cairo, Egypt, 27.

[11] WorleyParsons (2008) Environmental and Social Impact Assessment, ERC Hydro-Cracking Complex Project at Mostorod, Appendix 12.2-Clearance and Land Contamination Study Plan for North Plot and South Plot 1. Worley Parsons Infrastructure and Environment Limited, Maadi, Cairo, Egypt, 18.

[12] CERS (Center for Environmental Research and Studies) (2014) Method Statement of Groundwater Quality Baseline Study of ERC Refinery Project, Mostorod, Cairo, Egypt. Center for Environmental Research and Studies (CERS), Cairo University, Egypt, 19.

[13] Korany, E.A., Atwa, S.M., Abdel Baki, A.A. and Gad, M.I. (1997) Hydrogeochemical Regime and Functions of the Groundwater in the Area East of the Tenth of Ramadan City. 3rd Conference of Geochemistry, Alexandria, 3-4 September 1997, 23.

[14] Hefny, K. (1980) Groundwater in the Nile Valley. Ministry of Irrigation, WRCGR, Internal Report, 120 p. (In Arabic)

[15] RIGW (Research Institute of Groundwater) (1992) Hydrogeological Map of Nile Delta. 1st Edition, Scale 1:500,000, Nile Delta Sector.

[16] Kotob, A.M. (1988) Geological, Hydrogeological and Geoelectrical Studies on the Eastern Portion of Delta. M.Sc. Thesis, Al Azhar University, Cairo, Egypt.

[17] El Shamy, I.Z. and Mahmoud, S.M. (1999) Hydrogeochemical Investigation on the Groundwater at Cairo Belbeis District. 4th International Conference on Geochemistry, Alex, Egypt, 335-351.

[18] Al-Gamal, S.A., El-Sayed, S.A. and Ramdan, A.A. (2011) Assessment of Groundwater Fluctuation in the Miocene Aquifer, East Cairo District. Egyptian Journal of Geology, 55, 55-69.

[19] Abou Heleika, M.M. and Atwia, M.G. (2016) Integrated Electrical Resistivity and Hydrogeological Studies for Delineating the Miocene Aquifer at Eastern Side of Nile Delta, Egypt. Arabian Journal of Geosciences, 8, 4657-4667.

[20] Said, R. (1962) The Geology of Egypt. Elsevier Pupl. Co., Amsterdam, 377.

[21] Shukri, N.M. and Akmal, M.G. (1953) The Geology of Gebel EL-Nasuri and Gebel El-Anqabiya District. Bulletin Society of Geography, 26, 243-276.

[22] El-Sayed, S.A. (2005) Hydrogeological Studies and Application of the Environmental Isotopes Techniques on the Groundwater Resources in the Northeast Greater Cairo Area, Egypt. Ph.D. Thesis, Ain Shams University, Cairo, Egypt.

[23] CONOCO (1987) Geological Maps of Egypt Scale 1:500,000. Sheet Nos. NG 36 NW Cairo, The Egyptian General Petroleum Corporation, Egypt.

[24] El Fayoumy, I.F. (1968) Geology of Groundwater Supplies in the Region East of the Nile Delta. Ph.D. Thesis, Cairo University, 201.

[25] Sallouma, M.K.M. (1983) Hydrogeological and Hydrochemical Studies East of the Nile Delta, Egypt. Ph.D. Thesis, Ain Shams University, Cairo, Egypt.

[26] ASTM (American Society for Testing and Materials) (2002) Water and Environ- 
mental Technology. Annual Book of ASTM Standards, Sec. 11, Vol. 11.01, Vol. 11.02, West Conshohocken, USA.

[27] Todd, D.K. (1980) Ground Water Hydrology. John Wiley \& Sons, New York.

[28] EHCW (Egyptian High Committee of Water) (1995) Standards and Specifications of Water for Drinking and Domestic Use. Ministry of Health and Population, Egypt, 5. (In Arabic)

[29] EHCW (Egyptian High Committee of Water) (2007) Standards and Specifications of Water for Drinking and Domestic Use. Decision of the Minister of Health and Population No. 458 (2007), Ministry of Health and Population, 10 p. (In Arabic)

[30] Obeidat, M.M., Awawdeh, M., Abu Al-Rub, F. and Al-Ajlouni, A. (2012) An Innovative Nitrate Pollution Index and Multivariate Statistical Investigations of Groundwater Chemical Quality of Umm Rijam Aquifer (B4), North Yarmouk River Basin, Jordan. In: Voudouris, K. and Dimitra, V., Eds., Water Quality Monitoring and Assessment, InTech, Croatia, 169-188.

[31] Sahu, P. and Sikdar, P.K. (2008) Hydrochemical Framework of the Aquifer in and around East Kolkata Wetlands, West Bengal, India. Environmental Geology, 55, 823-835. https://doi.org/10.1007/s00254-007-1034-x

[32] Raychaudhuri, M., Raychaudhuri, S., Jena, S.K., Kumar, A. and Srivastava, R.C. (2014) WQI to Monitor Water Quality for Irrigation and Potable Use. Research Bulletin No. 71, 43.

[33] FAO (1985) Water Quality for Agriculture. Irrigation and Drainage Paper No. 29 Rev. 1, Rome, 182 p.

[34] Detay, M. (1997) Water Wells: Implementation, Maintenance and Restoration. John Wiley \& Sons, London, 379.

[35] Chebotarev, I. (1955) Metamorphism of Natural Waters in the Crust of Weathering. Geochimica et Cosmochimica Acta, 8, 22-32.

https://doi.org/10.1016/0016-7037(55)90015-6

[36] USEPA (United States Environmental Protection Agency) (2012) 2012 Edition of the Drinking Water Standards and Health Advisories Edition of Drinking Water Standards and Health Advisories. EPA822-R-04-005. https://www.epa.gov/sites/production/files/2015-09/documents/dwstandards2012

[37] Fadiran, A.O., Dlamini S.C. and Mavuso, A. (2008) A Comparative Study of the Phosphate Levels in Some Surface and Groundwater Bodies of Swaziland. Bulletin of the Chemical Society of Ethiopia, 22, 197-206. https://doi.org/10.4314/bcse.v22i2.61286

[38] Awad, M.A. and Abdel-Baki, A.A. (1993) Water Quality and Environmental Tritium for the Groundwater of the Quaternary Aquifer in Mostorad Station, Northward Cairo, Egypt. Bulletin of the Faculty of Science. Assiut University, 22, 173-191.

[39] Salem, W.M. (1996) Application of Isotopic Hydrochemical Techniques to Study Groundwater of the Eastern Nile Delta and Assessment of Pollution in Lake Manzala. Ph.D. Thesis, Cairo University, Egypt.

[40] EGSMA (Egyptian Geological Survey and Mining Authority) (1999) Regional Hydrogeologic Study. Unpublished Internal Report, No. I, EAEA.

[41] Geirnart, W. and Leaven, M.P. (1992) Composition and History of Groundwater in the Western Nile Delta. Journal of Hydrology, 138, 169-189.

https://doi.org/10.1016/0022-1694(92)90163-P

[42] Craig, H. (1961) Isotopic Variations in Meteoric Waters. Science, 133, 1702-1703. https://doi.org/10.1126/science.133.3465.1702 